\title{
Etnografik Belgeselde Jean Rouch'un Sinema Pratiği: Etno-Kurmaca
}

\author{
Bilgen $\mathrm{Kuzu}^{*}$
}

\section{$\ddot{O} z e t$}

Bu çalışmada Fransız Yönetmen Jean Rouch'un antropolog kimliğinin etkisiyle deneyimlediğgi ve kuramsallaştırdığı sinema pratiği Etno-kurmaca türü analiz edilmektedir. Çalışmanın amacında, yönetmenin "gerçeklere nüfus etmenin tek yolu" olarak tanımladığı etno-kurmacanın, biçimsel ve içeriksel olarak etnografik belgesel film yapımına etkisi irdelenmektedir. Bu bağlamda Jean Rouch'un yönetmenliğini yaptı̆̆ı "Jaguar" filmi üzerinden kültürel ve sinemasal kavramlar açıklanmakta ve etnografik film yapım sürecine kazandırdığı yenilikler belirtilmektedir. Kurgusal ve kurgusal olmayanlar arasındaki sınırın; kamera, kameraman, etnografik özne ve kavramlarla nasıl yapılandiğı açıklanmaktadır. Kültürel kavramlar, Rouch'un sinemasında önemli yer tutmaktadır. Rouch'un sinemasında "öteki" ile olan etnografik ilişki yönetmen kadar karakterlerin de sesinin duyulmasın sağlar. Film sürecinde "öteki" konumudaki özneler, filmin içindeki işbirliği ile dönüşerek paylaşımcı bir doğaçlama biçimi ortaya çıkmaktadır. Etno-kurmaca belgesel filmin "gerçek" unsurunun oluşturduğu katı sınırları yumuşatarak, gerçeğin temsiline farklı bir bakış açısı kazandırmaktadır. Gerçeğe dair yorumu da film kahramanlarına ve izleyiciye bırakmaktadır. Araştırmanın sonucunda Jean Rouch'un etno-kurmaca türü içinde uyguladığ̆ deneyimlerle, öykünün ve filmin kendi gerçekliğini yaratarak izleyiciye ulaştığı görülmektedir.

Anahtar Sözcükler: Etnografik belgesel sinema, Etno-kurmaca, Jean Rouch, Jaguar

*ORCID: 0000-0002-2223-4065

E-mail: bilgenince@gmail.com

DOI: 10.31122/Sinefilozofi.672116

Geliş Tarihi - Recieved: 01.08.2020

Kabul Tarihi - Accepted 20.04.2020 


\title{
Cinema Practice Of Jean Rouch In Etnographic Documentary: Etno-Fiction
}

\author{
Bilgen Kuzu*
}

\begin{abstract}
In this study, the ethno-fiction type of cinema practice that French director Jean Rouch experienced and theorized under the influence of his anthropologist identity is analyzed. The aim of this study is to investigate the effect of ethno-fiction, which is defined by the director as the only way to penetrate the reality, on the ethnographic documentary film production stylistically and contextually. In this context, cultural and cinematic concepts are explained through the Jaguar film directed by Jean Rouch and the innovations that have been introduced to the ethnographic film making process are mentioned. How the boundary between fictional and nonfiction is structured by camera, cameraman, ethnographic subject and concepts is explained in this study. Cultural concepts have an important place in Rouch's cinema. The ethnographic relationship with "the other" in Rouch's cinema makes the sound of characters as much as the director. In the film process, the subjects in the position of "the other" are transformed by the collaboration within the film and a form of improvisation emerges. Ethno-fictional documentary gives a different perspective to the representation of reality by softening the strict boundaries formed by the "real" element of the film. He leaves the interpretation of reality to the characters of the film and the audience. As a result of the research, it is seen that the story and the film have reached the audience by creating their own reality with the experiences they have implemented in the ethno-fiction genre of Jean Rouch.
\end{abstract}

Key Words: Etnographic documentary cinema, Etno-fiction, Jean Rouch, Jaguar

*ORCID: 0000-0002-2223-4065

E-mail: bilgenince@gmail.com

DOI: $10.31122 /$ Sinefilozofi.672116

Received - Geliş Tarihi: 01.08.2020

Accepted - Kabul Tarihi: 20.04.2020 


\section{Giriş}

Belgesel sinemanın izleyici üzerinde oluşturduğu güven duygusu onu kurmaca filmden ayıran en büyük özelliktir. Belgesel film izlerken, gerçeklerle yüzleşeceğimiz düşüncesi, yaşanmış bir olayın ya da eylemin anlatılacağı, bilinmeyen ya da unutulanla karşılaşacağımız duygusu benliğimizi sarar. Etnografik belgesel filmler unutulan, unutulmaya yüz tutan ya da bilinmeyen kültürlere bir keşif yolculuğudur.

“İnsan”, “kültür”, “toplum”, “yaşam”, “gelenek”, “kimlik”, “öteki” gibi kavramlar özellikle etnografik belgesel filmlerin beslendiği en önemli kavramlar arasındadır. $\mathrm{Bu}$ kavramları içine alan çalışmalar, uzun süreçleri kapsamakta ve özenli çalışma gerektirmektedir. Gerçeğe tanıklık etmek, güven sağlamak, gördüklerini etik olarak görüntülemek etnografik belgesel yönetmenleri için uzun ve sabırlı bir süreçtir. Kültürü, tarihi ve yaşamı kavramak, gözlemlemek, estetik ve etik değerler çerçevesinde izleyiciye aktarmak uzun uğraşlar sonucunda gerçekleşir. Bu noktada sinema, antropoloji, etnografik yöntem ve uygulamalar birbiriyle etkileşim içine girer ve filme yön verir. Bu yöntem ve uygulamaları başta teknik olmak üzere sinemanın tüm olanaklarıyla birleştiren Fransız Antropolog-Yönetmen Jean Rouch kendine özgü filmsel pratikler denemiş ve özellikle etnograf kimliğiyle "Etnokurmaca" türünü ortaya koyarak belgesel sinemada yeni bir kuram yaratmıştır.

Çalışmada, "kültürel antropoloji kavramları çerçevesinde, Jean Rouch'un "Jaguar" filmi üzerinden "Etnokurmaca"nın bu süreçteki etkisi ve önemi üzerine dikkat çekilmeye çalışılmıştır. Rouch'un uyguladığı farklı deneyimlerle, bu kavramların etnografik belgesel filmlere getirdiği anlayış ve yaklaşımlar incelenmiştir. Etnografik araştırma yöntemleri ile etnografik belgesel film yapım yöntemlerinin kesişim noktaları ve bu pratiklerin süreçteki etkileri açıklanmıştır. Bu süreçte, gözleyen ve gözlenen arasındaki etkileşim, belgeselcinin antropolog kimliği önemli unsurlardır.

Etnokurmaca; kurmaca ve gerçek, gözlem ve deneyim, bilgi ve duygu arasında itinayla çizilen çizgiyi yaratıcı bir şekilde ortadan kaldıran bir tür olarak karşımıza çıkmaktadır. Karşılıklı bir yapılanma sürecini kapsayan Etnokurmaca'nın "gözlemlenen" üzerindeki etkisi üzerinde durulmuştur. "Etnokurmaca"nın temsil filmi kabul edilen Jaguar, kültürel ve sinemasal kavramlar üzerinden açılanmaya çalışılmıştır.

\section{Etnografik Araştırma Yöntemleri ve Belgesel Film}

Sosyal bilimlerde birçok alanda kullanılan etnografik araştırma yöntemleri, kültürel antropolojide çeşitli kültürlere yönelik gözlem, inceleme yapmak ve veri toplamak amacıyla kullanılmaktadır. Antropolog Malinowski'ye göre; araştırmacı incelediği toplulukla en az bir yıl süreyle yaşamalı, yerel dili kullanmalı, kendi kültüründen olan kişilerden soyutlanmalıdır. Böylece kişi "onlar" kavramından "biz" kavramına bir geçiş yaşayacak ve bu durum araştırmacıya kültürü ve davranışları anlama, anlamlandırma ve yorumlamada bir iç görü sağlayacaktır (Akturan, http:/ / www.iticu.edu.tr).

"Onlar" kavramindan "biz" kavramına geçiş sürecinde antropolog incelediği topluluğun içinde uzun bir zaman geçirmektedir. Bu süreçte, ilk başta yabancılaşma yaşasa 
bile zaman içerisinde toplumun dinamiklerini daha kolay bir şekilde anlamaya başlar. "Etnografların en belirgin özellikleri, alana çıkmak ve başka insanların gündelik tecrübe ve faaliyetlerine yakın olmaktır. "Yakın olmak" kavramı en basit anlamıla insanların yaşamlarını ve yapıp ettiklerini içeren gündelik tekrarlara fiziksel ve sosyal açıdan yakın olmayı gerektirir; bu amaçla araştırmacı, başkalarını gözleyebilmek ve anlayabilmek için bu insanların yaşamlarının geçtiği kilit önemdeki yerlerin/bölgelerin tam ortasında bir konum edinebilmelidir (Emerson vd., 2008: 2).

Antropologların alan araştırma yöntemleri ve alan araştırmalarında kullandıkları teknik ve araçlar etnografik belgesel film sürecinde de kullanılmaktadır. Etnografik araştırma yöntemleri etnografik belgesel filmlerin bel kemiğini oluşturmaktadır. Belgesel film yönetmenin incelediği yaşama dâhil olması, bakış açısının gelişimi ve olaylara karşı duyarlılığının oluşması bakımından önemlidir. Etnografik belgesel filmlerin yapım sürecinde, belgesel film yönetmeni alan araştırmacısı gibi o hayatın akışı içinde yer alır ve toplulukla karşılıklı etkileşim halinde olur. Yönetmenin bu etkileşim sürecinde baktığını görebilmesi ve objektif aktarması açısından yerlileşme durumundan kaçınması gerekmektedir.

Etnografik araştırma yöntemlerinden biri olan "etnografik belgeleme, üzerinde araştırma yapılan toplumun kültürüne ait çeşitli unsurların fotoğraf, film, ses ve benzeri biçimlerde kaydedilmesi olarak tanımlanabilir. Hareketli resimler ve durağan fotoğraf saha araştırmalarının veri toplamada kullandıkları önemli araçlardır (Susar, 2005: 145).

Antropolojik araştırmalarda bu yöntemler toplumların kültürel yapılarının analiz edilmesinde kültürel bir araç olarak kullanılırken, etnografik belgesel yapım sürecinde yapılan bu analiz filmin özünü oluşturmaktadır. Etnografik belgeselin yapım sürecinde antropolojik bir bakış açısıyla başlayan yolculuk, sinemanın teknik ve olanaklarıyla kendi disiplinini ortaya koymaktadır.

Sinemacı etnograf Jean Rouch'un çalışmalarına baktığımızda; “Jean Rouch bir etnograftı ve başlangıçta sinemayı kendi araştırmaları için bir araç olarak görmekteydi" Makal, 2002: 38). Fakat çektiği etnografik belgesel filmler, zamanla belgesel sinemaya yeni bir boyut getirerek durum tersine dönüşmüştür.

Sürekli yeni deneyimlerin peşinde olan Rouch, etnografik belgeselin temel kurallarından ödün vermezken, bir yandan da yeni oluşumlardan yeni araştırma alanları çıkarılmasına ön ayak olmuştur (Altıntaş 2002: 33). Bu bağlamda Jean Rouch, hem belgesel sinemada hem de etnografik araştırmada kavramsal değişimlere yol açmıştır.

Öncelikle belgesel filmin içeriksel açılaması yapılmalıdır. “L. Herman'a göre; belgesel film, öyküsü gerçeğin içinden çıkan bir çalışmadır. Bu nedenle de gerçekçi bir konum içinde, öykünün geçtiği gerçek yerde ve öyküyle ilgili gerçek kişilerle uygulanır (Adal1, 1986: 14).

Belgeselin özgün yapısındaki güç, onun gerçeklere olan yakınlığından, araştırmaya ve yeniliğe açık, hatta bunları zorunlu kılan özelliğinden ve artistik karakterlerinden 
kaynaklıydı. Evet, belgesel film gerçekçiydi ve aynı zamanda yaşadığımız olaylarla ilgiliydi (Cereci, 1997: 11).

Belgesel sinema ve etnografik alan araştırması sürecindeki en önemli unsur, gerçeğin olduğu gibi belirlenebilmesi meselesidir. Bu yaklaşım içerisinde, belgesel sinemacı ve etnografın araştırma yöntemleri benzerlik göstermektedir. Etnografik belgesellerin yapım sürecinde, belgesel yönetmeni araştırma tekniklerini bir etnograf gibi uygulamaktadır. $\mathrm{Bu}$ süreç sonunda, etnografik belgeselin en büyük farkı, sinemanın imkân ve olanaklarını kullanarak ortaya koyduğu çalışmadır. Etnografik araştırma yöntemleriyle ortaya çıkan gözlem belge niteliğinden öte; bir söylemi ve duruşu olan, ticari belgesel mantığından uzak olarak sunulan gerçek bir dünyadır. Bu dünyada "gerçek" olgusunu yansıtabilmek etnografik araştırma ve film için zor bir meseledir. Başkalarının yaşamlarındaki çoklu gerçekleri ortaya koymak, etnograf ve belgesel film yönetmeninin ortak işidir.

Etnografik belgesel ve etnografik araştırma arasındaki farklılığa değinmek gerekirse ikisinde de öncelikler değişmektedir. “Etnografik belgesel, belgeselin taşıdığı estetik kaygıları ön planda tutmalıdır. Görüntülenmek istenen olgunun, olayın, durumun olduğu gibi doğal ortamına müdahale edilmeden kaydedilmesi gerekir. Etnolog için ise bilimsel kaygılar, estetik ve sanatsal kaygılardan önce gelir" (Susar: 2005: 147).

Antropoloji ve sinemanın yollarının kesiştiği kesindir. Fakat kültürel antropoloji çalışması için yapılan antropologların veri elde etmek için kullandıkları görsel etnografik belgeleri, etnografik belgesel film gibi değerlendirmek yanlış olacaktır. "Belge" öğesi kuşkusuz belgesel sinemanın en önemli unsurudur. Fakat belgesel film belge yığını değildir.

Burada, belgesel filmin betimleyiciliğinden de söz etmek gereklidir: Betimleme evrenseldir, tarih ötesi, kültür ötesidir. O sadece vardır, oradadır. Tıpkı yaşamın kendisi gibi. Bu dili öğrenebilmek ve gerçekte bu dilde kimin ne söylediğini ve nasıl söylediğini anlayabilmemiz ve onu daha anlaşılabilir bir şekildi kullanabilmemiz için, bu dili okumayı öğrenmemiz gereklidir. Sinemanın olayları, insanları, yaşamı betimleme amacıyla kullandığı dili de okumayı öğrenmemiz gereklidir. Kamera açılarını, duruş yerlerini, hareketlerini, kompozisyonları, ışılandırmayı ve bütün bu elemanların bir betimleme üretilirken birbirleri ile nasıl bir ilişki içinde olduklarını, müziğin eklenişini, diğer seslerin seçilişini ve kullanılışını, oyuncuları ve onların oyunlarını, diyalogları ve bütün bunların içindi bulunduğu ortamı tek tek okumamız daha sonra da okuduklarımızı birbirine ekleyerek gördüklerimiz 1şı̆̆ında yorumlamamız gerekmektedir (Pembecioğlu, 2005: 7).

Belgesel film yapımında belirli bir süreç uygulanır. Bu süreçte belgesele nasıl başlanacak? Nerede film çekilecek? Film ne hakkında olacak? Kimin üzerine odaklanacak? gibi sorulara cevap verilir. Pek çok kişi bir bölge, mekân seçerek işe başlamakta ve saha çalışması ya da ön araştırma sırasında belirlenmiş olan ne ise onu çekmeye karar vermektedir. Çok sayıdaki belgesel ve etnografik film yapımcısının, kendisini bir yöreye mekâna, ya da tek bir insan grubuna uzun dönemli olarak kendini adadığını görmekteyiz. Örneğin, Jean Rouch ve John Marshall, her ikisi de otuz yılın üstünde aynı grup insan üzerine çalışmışlardır (Susar, 2005:146). 
Etnografik belgeselciler, uzun süre çalıştıkları toplumlar üzerinden birçok önemli belgeseller oluşturdular. Uzun yıllara dayanan karşılıklı etkileşim; samimi ve doğal bir ortam oluşmasına olanak verirken diğer yandan yeni fikirlerin ortaya çıkmasını ve daha sonra bunların hayata geçmesini sağladı. Bu etkileşim ciddi gözlem gerektiren bir süreçti. Bu bağlamda, karşımıza etnografik belgesel film yönetmenlerinin ve etnografların uyguladığı gözlemleme yöntemleri çıkmaktadır.

\section{Katılımcı (Aktif) Gözlem ve Belgesel Sinemaya Etkisi}

Belgesel filmi, kurmaca filmden ayıran en önemli özellik gerçeklik olgusudur. Katılımsız gözlem ile dış dünyayı doğru bir şekilde anlamak ve bu doğrultuda gerçekleri aktarma çabası içinde olmak zordur. Etnografik araştırmalarda kullanılan yöntemler, belgesel film yapım sürecinde kendi yasalarını ortaya koymaktadır. Belgesel film çalışması yapılırken etnografik araştırma yöntemleri birebir olarak uygulanmaz. Etnografik belgesellerde sosyal ve kültürel ortamın belgesel değeri taşıyıp taşımadığı sorusuna verilecek olan cevap önemlidir. Belgesel sinemacının araştırma sürecindeki rolü, antropolog kimliğinden daha aktif ve belirleyicidir.

Nitel bir araştırma yapan belgesel sinemacı, katılımcı bir role sahiptir. Araştırma yapılan alanda zaman harcayan, alandaki kişilerle iletişim kuran, alanda olup biten olayları yaşayan kişidir. Üzerine belgesel film inşa edebilecek ham verileri toplama sürecinde belgesel sinemacı dış gerçeklikle, bilincinde oluşan imge arasındaki uyumun en üst düzeye taşınmasına özen göstermelidir (Yüksel, 2006: 207).

Örneğin Jean Rouch, uzun yıllar sonucunda gözlemlediği gerçeklikleri belgesellerine taşımaya çalışmıştır. Jean Rouch'un Nijer Songhay topraklarında yaptığı araştırmalarda, Nijer büyücüsünün çırağı olarak, topluluğun yaşamına tam anlamıyla dâhil olmuştur (Stoller, 1992: 214). Bu örnekte gözlemci, yabanc1 olduğu kültürün öğelerine aşinalık kazanarak, o toplulukla ilgili bilgilerini inşa etmeye başlamıştır. İlk zamanlar yabancılaşma yaşasa da, katılımcı gözlemle, adeta topluluğun bir bireyi gibi kültürel yaşamı deneyimlemiş olur. Bu durum gelecekteki etnografik uygulamaların merkezinde olacaktır.

Jean Rouch, özellikle Flaherty'in Kuzeyli Nanook "Nanook of the North" adlı filmini temel etnografik saha araştırması metoduna ait olan katılımcı gözlem ve geribildirimle benzerlik gösteren filmselliğin mucidi olarak görmektedir. Fakat ona göre, Flaherty bu keşfin bilincinde değildi. Rouch, filmi özellikle bir iletişim (izleyen ve izlenen) yönetimi olarak görmektedir; gözlemle sağlanan tanıdıklıkla, iletişim ve ortama dâhil olmakla gelen temas ve doğallık birleştirilmektedir. Filmin gözden geçirilmemiş kopyasını, çekildiği mekânda Nanook ve diğer Eskimolara izleten Flaherty, uyarım ve iletişim şekli olarak filmsel geribildirime öncülük yapmıştır (Rouch ve Feld, 2004: 12).

Flaherty için önemli olan ilk ilke, filmin yapım sürecinin öncesinde başlayan, yapım sürecinde de devam eden çalışmalarıdır. Grierson bu çalışmaların Flaherty de "araştırma ve araştırma özgürlüğünün gerçekliği olduğunu" belirtir. Araştırma Flaherty için filmini çekeceği insanlarla, kendi doğal mekânlarında onları tanıyana dek onlarla birlikte yaşamaktır. Bu nedenle Grierson, Flaherty'nin belgesel sinemanın iki ana ilkesini ortaya çıkardığını belirtir. Bunlardan birincisi; belgesel filmin gerecini olduğu yerde yakalaması ve 
gereci düzene sokmak için onunla içli dışlı olmasıdır. Flaherty bununla bir iki yıl uğraşıyor belki. Öyküsü kendi kendine söyleniverinceye değin, kişileriyle birlikte yaşamasıdır (Ulutak, 1998: 180).

Belgesel sinemanın ilk örneklerinde bilinçsiz bile olsa katılımcı gözlem metodunun uygulandığını görmekteyiz. Flaherty ile başlayan bu süreçte, filme çekilecek olan insanlarla birlikte yaşama durumu etnografik belgesel film anlayışında bir ilke haline gelmiştir.

Flaherty için filme çektiği insanlarla yaşamak, tek yönlü bir ilişkiye, başka bir deyişle salt film yapmaya dayanmıyor. Onların yaşamına girerek, onlardan biri oluyor. Aynı zamanda onlarda Flaherty'nin yaşamına girerek beraberce yaşamayı, beraberce film yapmayı beceriyorlar. Flaherty'nin önemli özelliklerinde biri de filme aldığı kişilere çektiği filmleri göstermek, onlarla filmi tartışmak. Flaherty Kuzeyli Nanook "Nanook of the North"un Eskimolarla birlikte kurulduğunu, ortaya çıtı̆̆ını, onlarsız hiçbir şey yapamayacağını, kısacası bunun bütünüyle bir insanca ilişkiler sorunu olduğunu belirtiyor. Böylece Flaherty salt kendi gözlemlerinden yaralanmıyor. Konusu olan kişilerin de kendi yaşamları hakkında görüşlerini değerlendiriyor. Çift yönlü iletişim, belgesel sinemanın önemli özelliklerinden biri oluyor. Filme konu olan insanlar, kendilerini başkalarına anlatma olanağı buluyor. Flaherty kendisi, seyircisi ve filme konu ettiği insanlar arasında kurduğu üçgen yapı ile karşılıklı iletişimi olanaklı kılıyor (Ulutak, 1998: 181).

Bu süreçte doğal yaşamın içine girerek, insan yaşamından çıkan gerçek öykülerin belgeselde konu olması önem kazanmaktadır. Bu katılımcı görüşmeler sonucunda gerçek insanların gerçek yaşamlarını bir öykü biçiminde önceden tasarlanmadan sunulması gerekmektedir.

Jean Rouch'un Bir Yaz Güncesi "Chronique d'un été" (1960) ve "Jaguar" gibi filmlerinde (1967), ortaya çıkan paylaşılan antropoloji ve katılımcı etnografı fikirleri yeni yöntemlere, yeni izleyicilere giden yolun kapılarını açmıştır (Susar, 2005: 144).

Jaguar filmi, Jean Rouch'un "paylaşımcı antropoloji” fikrinde önemli yer tutar. Jaguar, Rouch'un öteki'ni belgeleme ve açıklama girişimine değil, öteki ile arasındaki işbirliğine dayanmaktadır. Bu noktada, Rouch'un "paylaşımcı antropoloji" fikrinin hakikaten gerçekleştiğini açıktır. En basit formunda "paylaşımcı antropoloji", Flaherty'nin yaptı̆̆ı gibi, katılımcilarının imgelerini kaydeden ve onlar üzerine yorumlar yapan film yapımcısını içermez. Bunun yerine başlangıcından bitimine kadar tüm film projesi, tam bir ortak çalışmadan oluşur (Nannicelli, 2006:135).

Filmin gerçekleştirilmesi esnasında "paylaşımcı antropoloji" gözleyenle gözlenen arasındaki hiyerarşiyi ortadan kaldıran önemli adımlardan biridir. Ast-üst ilişkisinin bozulması "batılı bakış"ın daha nesnel bir bakış açısı kazanmasına olanak sağlayabilir.

Başka bir açıdan baktığımızda, katılımcı gözlem süreci içerisinde şu sorularla karşılaşmaktayız. Belgesel yönetmeninin gözlemci kimliği, aktif olarak o kültürün içinde bulunması ve etkileşim içinde olması belgeselde konu olacak kültürleri nasıl etkilemektedir? Belgesel yönetmeninin olguları etkileme ya da müdahale etme durumu olabilir mi? Belgesel yönetmeni gerçekten kendini o kültüre ya da gruba ait olarak hissedebilir mi? Belgesel film 
yönetmeni yüzde yüz doğal olanı ve gerçekleri filmine aktarabilir mi? Belgesel film yönetmeninin o kültüre ilişkin bildiği gerçekler seçimlerine nasıl yansımaktadır?

“Öykünün yaşamın içinden çıkarılmasında kullanılan en önemli araç Flaherty için kameradır" (Ulutak, 1998: 182). Sinemada öyküler kamera aracılığ1 ile hayat bulmaktadır. Etnografik belgesellerde yaşamın içinden çıkan öyküler, etkileşimler ve seçimler sonucunda kamera aracılığı ile aktarılmaktadır.

Flaherty'nin “Eskimoların içindeki yaşadıkları toplumsal, ekonomik, kültürel sorunları değil, kendi hayalinde yarattığı film kahramanı Nanook'u, Allakariallak'a oynatarak, hayali bir yaşamın "beyaz adam" için "merak edilebilir" öyküsünün anlattığını görmekteyiz (Ulutak, 1998: 156).

$\mathrm{Bu}$ örnek üzerinde etnografik belgesellerde "beyaz adam"ın bir anlamda kendi egemenliğini kurup, belgeselin sınırlarını önceden belirlediğini görmekteyiz. Etnografik belgesel film tarihi sürecinde, etnografik belgesellerin nesnel bakış açısından uzak ideolojik yapıtlar olarak kullanıldığı iddia edilebilir. Sömürgeci politikaların etkisiyle, kendi politik çıkarları doğrultusunda kendi gerçekliğini yarattığı söylenebilir.

Flaherty'nin 1926 yılında Sinema Mühendisleri Birliği'nde yaptığı konuşmasında anlattığı Allakariallak, filmde anlatılan Nanook'tan çok farklıdır. Ayda beş dolardan az bir maaşla "beyaz adamı" (komisyoncunun ve sonrasında Flaherty'nin) yanında hizmetli olarak çalışmaktadır. Allakariallak'ın bu kimliğinin izleyiciden saklanıp onun bir "şef" "büyük avcı" ve arkadaşlarının "dünyanın en neşeli insanları, korkusuz, sevimli, mutlu Eskimoları" olarak tanıtılması, beyaz adamın yani Flaherty'nin batı uygarlığına nasıl bir öykü kahramanı sunduğunu gösteren önemli bir kanıttır. Filmde Allakariallak ve diğerleri kendilerini oynamaktadır ama bu oyunun kuralların belirleyen ve izleyiciye Nanook'un öyküsünün anlatan Flaherty'dir. Ancak anlatılanın bir öykü olduğuna ilişkin ipucu izleyiciye Flaherty tarafından verilmemektedir (Ulutak, 1998: 16-17).

Sonuç olarak, Robert Flaherty, Jean Rouch ve birçok etnografik belgesel film yönetmeninin çalışmalarını, gerçekleştirdikleri dönem içinde değerlendirmek doğru olacaktır. Belgesel sinemanın ilk yönetmenlerinden Robert Flaherty, çektiği belgesellerde bilinçsiz bir tutumla ilk örnekleri gerçekleştirmiştir. O dönemin şartları içerisinde, sinemanın kısıtlı olanaklarıyla Kuzey Kutbu'na gidip belgesel çekmek önemli bir başarıydı. Bunun karşısında antropolog olarak yetişmiş ve bunu daha sonra sinemacı kimliğiyle bütünleştirmiş olan Jean Rouch, etnografik belgesel anlayışına önemli bir boyut kazandırmıştır. Jean Rouch'un ortaya attığı ve uyguladı̆̆ı fikirlerle, sömürgeci zihniyetin yönlendirdiği etnografik belgeleme dönüşüme uğramıştır. Bu süreçte, ilkel topluluklara olan bakış açısının, az da olsa farklılık gösterdiği söylenebilir.

\section{Etnokurmaca, Doğaçlama ve Sine-Trans}

Jean Rouch'un sinemasına bakıldığında; 1946 yılından ölümüne kadar gerçekleştirdiği belgesellerde, geleneksel bakış açısından "etnokurmaca"ya uzanan bir serüvene tanıklık edilmektedir. Rouch, zaman içerisinde kendisine yapılan eleştirileri 
dikkate almış, antropolojik ve sinemasal pratiğini geliştirerek etnografik belgeselin yapım sürecine yenilikler kazandırmıştır.

"Etnokurmaca" film olarak kategorize edilmeye karşı çıkmaktadır. "Etnokurmaca" ne gözlemlenmiş hakikatin yansıtıldığı belgesel, ne de seyirciyi duygusal olarak coşturmaya çalışan melodramdır. Bu tip filmler uzun yıllar süren zahmetli araştırmalar sonucu ortaya çıkan etnografilere dayalı hikâyelerdir. "Etnokurmaca"yla Jean Rouch, kurmaca ve gerçek, gözlem ve deneyim, bilgi ve duygu arasında itinayla çizilen çizgiyi yaratıcı bir şekilde ortadan kaldırır (Koçer, 2008: 52). Bu noktada kurmaca ve gerçek kavramlarının sorgulanması gerekmektedir. Kurmaca kavramı sinemada bildiğimiz klasik anlayışın aksine, uzun bir zaman sürecinde oluşan, gözlemlenen kişilerin doğaçlama yaratısı ile oluşur. Bunun sonucunda kültürel gerçekliğin bir sureti "etnokurmaca" ile yansıtılmaktadır.

Rouch, öğrendiği en önemli şeyin kamera ve filmin özne ve nesne, hakikat ile kurmaca arasındaki ilişkiyi dönüştürebilen benzersiz niteliği olduğudur. Sinemasal ve etnografik hakikat; kamera, kameraman ve etnografik özneler arasındaki diyalogdan doğan ve bu ilişki içinde var olmayan karşılıklı bir yapılanma sürecinin sonucunda ortaya çıkar (Koçer, 2008: 51). Gözlemleyen ile gözlemlenen arasındaki etnografik ilişki, kamera ile nesne arasındaki ilişki ile benzerlik göstermektedir. Fakat kameranın varlığının dönüştürücü etkisi kurmaca ile hakikat arasındaki çizgide gidip gelmektedir. Kameranın etkisiyle belgesel film yönetmeni pasif izleyici olan etnograftan daha aktif bir konumdadır.

Rouch'un filmde etnografik anlayışı nasıl kullanacağına dair düşüncelerine şekil veren en önemli yönetmenlerden biri Robert Flaherty'dir. "Flaherty, Nanook of the North'un çekimleri esnasında, filmi stüdyo dışında banyo edebilmek ve Nanook ve ailesinin gündelik hayatını görüntüleyebilmek için mükemmel bir improvize film laboratuvarı kurar. Daha sonra Flaherty söyle yazıyor: "Benim için o gün çektiklerimi görebilmek her zaman çok önemli oldu. Bu benim film yapabilmem için tek yoldu. Fakat filmi Kuzey'de banyo etmemin bir başka önemli nedeni, onu Eskimolara gösterebilmekti, böylece ne yaptığımı anlayıp, kabul edebilecekler ve benimle birlikte ortak çalışabileceklerdi" (Nannicelli, 2006: 125).

Rouch da, aynı tavrı katılımcılarına filmi izletip onların fikrini sorarak takip eder. Rouch'un pratiğinin merkezini oluşturan "katılımcı kamera" Flaherty tarafından ortaya atıldı. Aslında Flaherty, katılımcıların film sürecini anlamalarını garanti altına almak için, çektiği metrajları onlara göstermek zorundaydı, bunun sebebi sadece Rouch'un belirttiği gibi, "en temel dürüstlük çabasının anlamı olan çekilen metrajları bireylere göstermek" değil, aynı zamanda, Flaherty'nin filmde göstermek istediği dünyayı kurabilmek için, bu insanların yardımına ihtiyaç duymasıydı (Nannicelli, 2006: 126).

Rouch'a göre, "etnokurmaca"yı hayata geçirmenin iki ön koşulu vardır. Bulardan ilki öznelerle yönetmen arasında uzun süreli etnografik ilişki üzerinde temellendirilmiş diyalog, ikincisiyse kamerayı katılımcı kılan estetik ve teknik seçimlerdir. Tripot yerine el kamerası, zum yerine sabit lens kullanmak katılımcı kılan seçimlerden bazılarıdır (Koçer, 2008: 51).

O dönemdeki teknik ekipmanların taşınabilir nitelikte olması, "etnokurmaca"nın gerçekleşmesinde önemli bir rol oynamıştır. Teknik daha geride olsaydı, alıcının gerçek 
hayatın içinde katılımcı olarak bulunması zorlaşacak ve "etnokurmaca"nın en önemli koşullarından biri var olamayacaktı.

"Etnokurmaca"nın bel kemiğini ekibin her üyesinin yerel dili akıcı bir şekilde konuşması oluşturur. Ses operatöründen kameramana, yapım amirinden araştırmacıya, kadar tüm ekibin etkin bir şekilde yerel kültür ve dille iletişim halinde olması, neredeyse mümkün olmadığından, Rouch profesyonel ekiple çalışmak yerine yerel özneleri prodüksiyonun çeşitli aşamalarında sorumlu olmak üzere eğitir (Koçer, 2008: 51).

"Etnokurmaca" türü bir anlamda Jean Rouch'un kültür, sahne, gerçek, kurmaca gibi sine-etnografik tematiklerinin bir sentezidir. Etnokurmaca gerçekle kurmaca arasındaki bulanık bir sınırı temsil eder. Belgesel ile kurmaca arasındaki ince çizgi, etnograf ile film yapımcısı arasındaki ilişki ile benzerlik gösterir. İş birliği anlayışının öne çıktı̆̆ı bu kavramda, "gerçeğin sahnelenmesi" insan ilişkileri temelinde gerçekleşmektedir. Kamera dışı ilişkilerin film sahnelerine yansıdığı açıkça gözlemlenmektedir.

"Etnokurmaca" belgesel sinemanın "gerçek" unsurunun oluşturduğu katı sınırları yumuşatarak, gerçeğin "temsiliyet" olasılığına farklı bir bakış açısı getirmektedir. "Etnokurmaca" bir anlamda gerçekliğe dair yorumunu yapımcısından alarak, kahramanlarına ve izleyicisine birakmaktadır.

Jean Rouch sinema ile gerçek hayatın yorumunu; yalnızca kamera, sahne, ilişkiler üzerinden değil, anlatım yapısı ve sunumu ile de gerçekleştirmektedir. Jaguar'da kullanılan doğaçlama diyaloglar "gerçekliğin" özneler tarafından inşasının önemli göstergesidir. Bir anlamda gerçeklik alanında, gerçekliği tasvir eden bir anlayış öne çıkmaktadır.

Doğaçlama ve sine-trans denemeleri, Rouch'un sineması için şiirsel bir anlatım sürecini ifade etmekteydi. Doğaçlama dinamiklerini oluşturan en önemli özelliklerin başında, Rouch'un "paylaşımcı antropoloji” ve "katılımcı kamera" düşüncesi gelmektedir. Etnografik belgesel film yapımında, doğaçlama ve sine-trans uygulamaları, gösterilmek istenilen dünyayı kurabilmek için kahramanlarla yapılan bir işbirliği niteliğindeydi. Enrico Fulhignoni Jean Rouch'la yaptığı söyleşide doğaçlama üzerine şunları ifade etmiştir: "Kelime ve mimiğin sanatı olan doğaçlamaya kendimi teslim ettim. $\mathrm{O}$ an bilinmeze dâhil olunuyor ve kamera olayları takip ediyor. Bu çok kolay bir formüldür. Çoğu kez, çektiğim sahnenin sonunda ne olacağını bilmem ve böylelikle hiç canım sıkılmaz. İyi ya da kötü doğaçlamaya zorlanırım. Bu durum filme olağanüstü canlılık katıyor" (Rouch ve Feld, 2004: 149). Jean Rouch'un Afrika'da uzun yıllar yaptığı alan araştırmalarının doğaçlama süreçlerine etkisi büyüktür. Rouch'un aktörlerinin doğaçlamasına bu kadar çok güven duymasının önemli nedeni, onları çok iyi tanımasından kaynaklanmaktadır.

$\mathrm{Bu}$ süreçte, insanlar kendilerini ifşa ederek tepki verir ve anlamlar bu ifşada oluşmaktadır. Drama, ifşa etmenin ve filme çekme eyleminin içinde doğal olarak yer almaktadır. Kişisel anlatı açısından doğaçlama, hayatın dramasını yakalamanın en doğru yoludur (Rouch ve Feld, 2004: 16).

Etnografik film yapımcısı David MacDougall, Jean Rouch için söyle demiştir: “Rouch'un Batı Afrikalılar ile ilgili yaptığı filmlerde, onların kendilerini ifade edeceği şekilde 
film çekmeye çalışmış olduğu hissedilebiliyor" sözleri Rouch'un doğaçlama deneyimlerinin başarısını ortaya koymaktadır (Rouch ve Feld, 2004: 17). Aslında, Rouch bir anlamda film çekme sürecinin içine onları aktif olarak dâhil ederek, kendi doğal gerçekliklerini oluşturmalarına imkân vermiştir. Müdahale etmenin etkilerinin doğal süreci bozduğunu bir önceki çalışmalarında fark eden Rouch, bu yöntemle o insanlara kendilerini ifade etme fırsatı tanımıştır.

Jaguar filminde "Damouré, Illo, Lam, Duma ve Jean etkin ve kolektif bir doğaçlama süreci içerisinde hakikati kamera yardımıyla beraber yaratırlar. Seyirci ortaya çıkan üründe, Jean Rouch'un sesi kadar filmin öznelerinin de sesini duyar" (Koçer, 2008: 52). Jean Rouch'un film çalışmalarına baktığımızda, Jaguar filmine kadar doğaçlama pratiklerinin oturuşmadığı ve ilk film çalışmalarında batılı önyargılı bakış açısı içersinde bulunduğu gözlemlenir. Kamera ve Rouch'un hayata olan mesafesi, katılımcıların öznelliğini yok etmektedir. Rouch için bu deneyimler, sonraki filmleri için bir ders ve hazırlık niteliğindedir. Rouch'un Jaguar filminde gerçekleştirdiği doğaçlama süreci, etnografik belgeselde "öteki" olarak yer alan kişileri filmin yapımcısı kadar önemli bir konuma getirmektedir. Bu durum, yapımcının egemenliğinin olmadığı, öteki ve film yapımcısı arasındaki sınırların kalktığının göstergesidir. Artık, burada film yapımcısı ile öteki arasında somut bir işbirliği vardır.

Çekimleri 1954'te başlayan ve son halini 1967'de alan Jaguar filminin gerçekleştirilme evresini sağlayan koşullarda, doğaçlamanın en önemli kısmını oluşturmaktadır. Jaguar'ın konusu, filmin ana karakterlerinden Damouré Zika tarafından önerilmiştir (Koçer, 2008: 52). Damouré Zika Rouch'a “Biz oynayacağı" der. Damouré, Illo, Lam, Duma ve Rouch'un bildikleri tek şey filmin ve başı ve sonudur (Stoller, 1992: 137). "Yol boyunca karakterlerin karşılaştıkları olaylar, Rouch tarafından spontane olarak kaydedilir" (Koçer, 2008: 52). Gana'ya mevsimlik göçü konu alan film, doğaçlama biçimde gerçekleştirilir. Aslında, etnokurgu denemelerinin başlangıç noktası bu paylaşımcı doğaçlama sürecinde yatmaktadır. Gerçek hayatın üzerinden oluşturduğu kurgu doğaçlama, anlatım yapısı ile birleşerek şiirsel bir hikâye oluşturmaktadır. "Eleştirmenler Jaguar'ı ilham verici, lirik, duygulara ve insana dair keşiflerle dolu bir film olarak nitelendirmişlerdir" (Stoller, 1992: 138).

Filmin çekimi boyunca devam eden doğaçlama pratikleri, senkronize ses teknolojisinin olmaması nedeniyle film bittikten sonra devam etmiştir. Bu teknolojik talihsizlik, belki de doğaçlama uygulamasının son aşamasının oluşmasına neden olmuştur. Jaguar filminin çekimleri sonunda film kahramanları stüdyoda filmi izleyerek üzerine doğaçlama anlatımlar yaptılar. "Rouch, bu durum karşısında iyice düşünüp taşındı. Yorumların kahramanların neşeli ruhlarıyla nasıl uyum sağlayacağı hakkında endişeliydi. 1957 yılında Gana Film'den bir meslektaşı, onu Accra'da bir ses stüdyosuna davet etti. Rouch, Damouré ve Lam'dan Jaguar'ın çekimlerini izleyerek konuşmalarını istedi. Rouch, onların görüntü bazlı konuşmalarını kaydetti. İki gün içerisinde ses kayıtlarını filme eklediler" (Stoller, 1992: 138). Diyalogların ve yorumların doğaçlama olarak kayıt edilmesi, bu filmin oluşumunda çok önemli bir süreçti. Çünkü kahramanlar sessiz film üzerine kendi anlatımları ile öznel gerçekliklerini kazımışlarıdır. Kamera ile üretilen görüntü, doğaçlama yorumlarla izleyiciye aracısız bir anlatım olanağı sağlamaktadır. Buradaki anlatım, klasik bir 
açılamadan öte kültürün doğal ve samimi bir yorumu hatta yer yer başkaldırısı olarak karşımıza çıkmaktadır.

Sine-trans, Rouch'un sinemasında deneysel ve gözlemsel olarak kültürle kurduğu bağ sonucunda oluşan bir anlatı biçimini ifade etmektedir. Sine-trans kültürlerin ritüellerinin gerçek transının filmsel trans haline geçiş süreci olarak karşımıza çıkar. Bu süreç Rouch için güvenirliğin ve sabrın sonucunda oluşmuştur. Rouch, sinema sanatı için şu sözleri söylemiştir. "Bence, sinema anlık ve ani olanın, sabrın ve zamanın sanatıdır" (Rouch ve Feld, 2004: 17).

Rouch'un etnografik belgesel film alanında, sine-trans ve buna benzer tematiklerini uyguladığı en önemli yapıtı 1955 yılında gerçekleştirdiği Çılgın Efendiler "Les maîtres fous" adlı filmidir. Batı Afrika'nın dinsel töreni olan Hauka Töreni sine-trans denemeleri üzerinden filme alınmıştır. Burada, Accra'da yaşayan halkın "Hauka" ritüelinin etnografik bir öğe olarak aktarılmasından daha önemlisi, Rouch'un belgesel sinema adına uyguladığı deneyimleridir. Tüm yaşamı boyunca Afrika kültürü üzerine aktarımlarda bulunan Rouch, bu filmi antropoloji bilgisi ile zamanın şartları ve teknolojik yeterlilikleri doğrultusunda yapılandırmıştır.

Rouch'un, "Hauka" ritüeline filmi çekmeden yedi yıl öncesinden aşina olduğu bilinmektedir. Rouch yüz kadar tören izlediğini ve onları çok iyi tanıdığını ifade etmiştir. Daha da önemlisi, Accra kökenli Hauka rahipleri, Rouch'tan törenlerinin birini onlar için filme almasını ister (Rouch ve Feld, 2004: 188). Hauka ritüelini birçok kez izleyen Rouch'un bu konu ile ilgili kapsamlı bir saha çalışması yaptığı ortadadır. Rouch'un bu çalışmasının öncesinde 1948-1949 y1lları arasında gerçekleştirdiği Wanzerbe Büyücüleri "Les Magiciens de Wanzerbe" adlı filminde yine dinsel bir ritüeli görüntülemiştir. Stoller, iki film arasındaki süreci şu şekilde ifade etmektedir: Büyücülük genellikle özel/gizli olarak uygulanırken, ruh teslimiyeti çok daha teatral ve halka açık olarak uygulanır. Bu yüzden, büyücülük töreni Rouch'u daha geleneksel, gözlemsel model ile sinırlarken, Hauka töreni film yapımcısının öznesi ile bir ilişki tarzı geliştirip, etkileşim olanakları sunmuş; Rouch'u biçim ve temsil alanında daha özgürce de Znemeler yapabilecek şekilde rahatlatmış olabilir (Stoller, 1992: 188).

Rouch'un Hauka ile olan deneyimleri, öznelerini daha iyi yansıtmasını ve temsil etmesini sağlarken, Hauka rahiplerinin törenlerini filme almalarını istemeleri, açık olarak yapılan işbirliğinin göstergesidir. Bu süreçteki en önemli unsur, öznelerin bu filmi gerçekleştirme istekleridir.

Trans kavramı, burada karşılıklı bir etkileşimi sembolize etmektedir. Ritüelin gerçek trans halinden, filmsel trans haline geçmesi iki durumun birbirini tetiklemesiyle oluşmaktadır. "Rouch'a göre, Hauka'nın bu törenin filme alınmasını talep etmesinin nedeni, sinemayı diğerlerini transa geçirebilecek bir araç olarak deneyimlemek istemeleridir. Rouch şöyle belirtir: "Transa geçen insanlar neredeyse tehlikeli bir şekilde kontrolden çıtı. Fakat rahipler bunun farkındaydı. Sanırım, amaçları daha önceden yapılanın ötesine geçmekti" (Nannicelli, 2006: 131). 
Rouch'a göre, kamera ruhun bedene sahip olması fenomenini hızlandıran ya da serbest bırakan sihirli bir nesne haline gelir. Çünkü ritüelin film yapımcısının gözleri önünde cereyan etmesi onu ulaşmaya cesaret edemeyeceği yollara iter, bu noktada sinematografik yaratıc1lık ortaya çıkar (Rouch ve Feld, 2004: 183).

Rouch, Çılgın Efendiler "Les maîtres fous" filmini çektiği zaman eşzamanlı ses kayıt teknolojisi henüz geliştirilmişti. Film esnasında çıkan vahşi sesleri, Damouré Zika kaydeder ve Rouch'da Hauka'nın anlaşılmaz seslerini, daha sonra stüdyoya girerek, kısmen kendi çevirisinden oluşan bir metinle seslendirmeyi düşünür. Daha sonra, Rouch doğrudan çevirinin imkânsız olduğunu fark eder ve kabile/kült mensuplarından birinin yardımıyla tüm seslendirmeyi bir çeşit sine-trans (ciné-transe) halinde doğaçlar - sanki töreni izlerken ele geçirilmiş gibidir (Nannicelli, 2006: 130).

Gerçek bir trans halinden film transına geçiş sürecinde, Rouch'un kendini ritüele dâhil etmesinde kamera ve ses teknolojisi büyük önem taşımaktadır. Kendi istekleriyle çekilen ritüelde, kamera harekete geçirici olarak rol oynarken, kullanılan doğal sesler ve sahada kaydedilen müzik, çekilen yakın plan yüzler, izleyicinin de kendini ritüelin içinde hissetmesini ve transa geçmesini sağlayabilir.

Sine-trans, bir yönden de izleyici üzerinden oluşturulan bir deneyimdir. Ritüelin görsel ve işitsel baskınlığı, izleyicilerin de transa geçme ihtimalini güçlendirir.

Scheinman'a göre, “Tek telli bir keman tarafından çalındığını duyduğumuz ve transa eşlik eden müzikal motifler, Hauka ruhunu 'çă̆ırmak' ve 'atlarının' içine girmesi için kullanılır; bir hauka izleyicisi için bu sekans, transa neden olabilecek işitsel ve görsel uyarılar arasındaki ilk çatışmadır" (Scheinman, 1998: 198).

Film esnasında kullanılan Rouch'un dış sesi de, sine-transın etkisinde önemli rol oynamaktadır. Kaydedilen "öteki" müziğin ve doğal ortam seslerinin filmde dış sese oranla baskın olması, Rouch'un ritüel üzerindeki kontrolünü azaltmaktadır. Rouch daha önce belirttiğimiz gibi, sine-transta anlatımı kabile mensubundan yardım alarak gerçekleştirerek çekim sürecini Hauka Ritüeline bağımlı hale getirmektedir. Diane Scheinman' ın belirttiğine göre, Çılgın Efendiler "Les maîtres fous"da Rouch'un diş sesi fonda sıklıkla yitip gider, bu da sahada kaydedilen müziğin ve Hauka'nın sihrinin ortaya çıkmasını sağlar.

\section{Jaguar: Gerçekle Kurmaca Arasında}

Şimdi cadde boyunca yürüyorum, ben Jaguar'ım

- Jaguar ne demek?

- Jaguar, hoş saç tıraşı olan, güçlü, genç adam demek. Sigara içer, etrafta dolaşır, herkes onu izler, İște Jaguar'ın anlamı bu.

Jaguar (Jean Rouch 1967) adlı filmden Damouré Zika'nın doğaçlaması

Çekimleri 1954'te başlayan ve son halini 1967'de alan Jaguar, Rouch'un Afrika'da uzun yıllar sürdürdüğ̈̈ alan araştırmasına dayanır; Songay'l erkeklerin mevsimlik işçi olarak bugünün Gana'sına göçünü konu alır. 
Üç genç adam üzerinden anlatılan hikâye; Giriş (kahramanların tanıtımı), yolculuğa hazırlık, yolculuk (kahramanların yola çıkması), ayrilış (kahramanların birbirinden ayrilması), Accra'da yaşamları, buluşma ve Ayorou'ya dönüşleri üzerinden anlatılmaktadır.

Jaguar, Jean Rouch'un "paylaşımcı antropoloji" fikrini bütünüyle gerçekleştiği temsil filmi olarak kabul edilir. Rouch'un Flaherty'in etkisiyle benimsediği bu fikir, diğer filmlerine kıyasla Jaguar'da hayata geçmektedir. Filmin ortaya çıkma sürecinin başında, fikrin kahramanlardan biri olan Damouré Zika tarafindan önerildiği bilinmektedir. Damouré Zika, filmde kendilerinin oynamak istediğini ifade eder. Bu bağlamda, filmin öznelerinden birinin filmi yapılandırdiğı gözlenmektedir. Bu çok önemli bir süreçtir. Bu durum, antropolog- yönetmen ile öteki arasındaki işbirliğinin ve paylaşımc antropoloji fikrinin de hayata geçtiği gerçeğinin somut bir örneği olarak karşımıza çıkmaktadır. Film çekimlerinin başlangıcından bitimine dek, filmle ilgili bilinen tek şey filmin başı ve sonudur. "Etnokurmaca" bu noktada başlamakta ve "paylaşımo antropoloji" kavramı hayata geçmektedir. Damouré Zika ile arkadaşlar filmi doğaçlamaya karar verirler. Jaguar, geleneksel etnografik filmlerdeki gibi "öteki"'ni ya da "öteki toplum"larn belgeleme durumundan öte, filmin başlangıcından bitimine kadar ortak bir çalışmanın ürünü olarak doğmuştur. Filmin ortak bir doğaçlama sürecinde oluşması, Rouch'un film üzerine müdahale etme olasılığı durumunu azaltmakta, böylece filme kendi ideolojisinin ve gerçekliğini ortaya çıkarma şansını tanımaktadır. Burada, Rouch'un belgesel üzerindeki etkisinin tamamen ortadan kalktı̆̆ın söylemek yanlış olacaktır. Fakat yerel öznelerin sesinin Jean Rouch kadar, belki de yer yer daha fazla duyulduğu ifade edilebilir. Rouch'un Afrika'da uzun yillar yaptığı alan araştırmaları sonucunda çektiği birçok film, kültürel sürece ve olgulara uyum sağladığının da göstergesidir. Bu uyum sürecinde, Rouch'un yerel öznelerle ortak bir bakış açısı içinde batılı dünyaya başkaldırdığı açıktır. Böylelikle, etnografik belgesel film yapım sürecinde katılım çok önemlidir. Rouch'un yerel kültürlere kendini dâhil ederek uzun süreli olarak kendini adayışı ve kişilerle kurduğu iletişim, filmin yapım öncesi sürecinin temelini oluşturmaktadır.

Film, "Bu hikâye filmle alındı̆̆ında Afrika henüz bağımsız değildi ve Altın Kumsal henüz Gana olarak bilinmiyordu." açıklamasıyla başlar. Jaguar, etnografik bir anlayışla yapılmıştır. Filmin ilk kareleri, Ayorou'nun genel görüntülerinden oluşmaktadır. Kahramanların yaşadığı coğrafi mekânla ilgili bilgi sunulmaktadır. Gökyüzünden aşă̆ıya doğru yapılan dikey kamera hareketi ile izleyiciye egzotik mekânın ilk kareleri ard arda verilmektedir. Bu ilk karelerle, Jean Rouch klasik etnografik belgesel filmlerdeki tipik sahneleri tekrar etmektedir.

Rouch, filmin başında bize anlatacağı hikâyeden kısaca bahsetmektedir. Rouch'un sesinin film boyunca baskın olmaması, film süresince kısa anlatımlarda bulunması onu yönlendirici konumdan, yardımcı bir hikâye anlatıcısına dönüştürmektedir. Film, üç kahramanın (Lam Ibrahima Dia, Illo Gaoudel, Damouré Zika) tanitılmasıyla devam eder. Kahramanlarm doğal sesler ve doğaçlama anlatımlarla tanıtan Rouch, izleyiciye kahramanlarla ilgili kültürel bilgileri de aktarmış olur. Böylelikle, izleyici kahramanların yaşadığı yer, yaptı̆̆ı işler, giydiği kıyafetler, toplumsal roller gibi kültürel öğeleri algılayabilir. Üç genç adam, savaşçı ve cesur tavırlarıla gerçek bir kahraman gibi nitelendirilir. Bu özellik, belgeselde uygulanan etnografik yaklaşım çerçevesinde önemlidir. Üç arkadaş, her hafta Ayorou'daki pazarda buluşmaktadır. Ayorou pazarmın kültürdeki önemi vurgulanırken, düğ̈̈n, savaş, yolculuk gibi kararların burada alındığı söylenir. Farklı sosyal deneyimlere sahip olan genç erkeklerin buluşma noktası burasıdır. Ayorou onlar için önemlidir, çünkü yolculuğa burada karar verilmiştir. Etnografik kodlarla birlikte devam eden film, diğger taraftan üç 
ortak arzuda birleşen ü̧̈ kahramanın bilinmeyen ve macera dolu yolculuğuna izleyiciyi hazırlamaktadır. Yolculuk başlamadan önce, Müslüman halkın gittiği "Wallima Töreni"ne katılan kahramanlar dua ederler. Ayrıca, bir ruh ayinine katıldıklarn gözlemlenir. Rouch'un filmlerinde, inançların ve ritüellerin önemli olduğu bilinmektedir. Jaguar'da farkh inanışların görselleri ve doğal sesler aracılığıyla izleyici filmin içine çekilmektedir. Üçlü'nün bu ayinlerin dişında yola çımadan önce, Wanzerbe büyücüsü Mossi Bana'ya danıştıklarını gözlemlenir. Buradaki Mossi Bana karakteri, daha önceden Rouch filmlerinden bilinen ünlü bir büyücüdür. Yola çıkmadan önce büyücülere danışmak, Nijer halkı için önemlidir. Mossi'nin deniz kabukların yere atarak baktığı fal, Rouch tarafindan anlatılır. Mossi üç genç adama yollarının kötü olduğunu söyler. Kazalar ve hastalıklar görür. Mossi, onlara sınırı geçtikten sonra ilk yol ayrımında ayrılırlarsa, bu talihsizliklerden korunabileceklerini söyler. Bu tavsiyeler Mossi'nin de filmin senaryosunu yönlendirdiği anlamında düşünülebilir. Çünkü Lam, Illo ve Damouré Altın Sahil'e bu tavsiyeler doğrultusunda yola çıkarlar. Doğaçlama pratiği açısından filmin önemli bir noktasını oluşturan bu bölüm, filmin değişim sürecinin de başladığı yerdir.

Kahramanların macera, değişim, korku, ötekilik hikâyeleri başlamıştır. Bilinmeyene doğru başlayan yolculuğun antropolojik bir alan deneyiminden daha öte olduğu ortadadır. Kahramanlar ilerledikçe, iklim, bitki örtüsü ve insanlar değişmektedir. Dikenli ağaçlarla dolu kuru bir çöl olan bölgeden, dağlık bölgelere ulaşılır. İlk durak onlar için Somba köyüdür. Burası izole bir bölgedir. Suyun bol olduğu bir köydür. Kahramanlar burada ilk kez “öteki"'ni deneyimler. Buradaki “öteki” Sombalılardır. Çıplak Somba kadınları ve erkekleri utanmanın olmadığ tarafından şaşkınlıkla karşılanır. Somba pazarında Pipo içen kadınlar ve Somba erkeklerinin taktığ1 gözlük ve şapkalar küresel dünyanın simgeleri olarak yerel kültürde ön plana çıkmaktadır. Filmin önemli sahnelerinden birini oluşturan bu bölüm, "öteki"'nin de "öteki"si olduğu gerçeğini yansıtmaktadır. Aslında, burada iç içe geçmiş çoksesli bir anlatım söz konusudur.

Somba halkının kültürel yaşam biçimleri kahramanlarımız tarafından doğaçlama yorumlanırken, Rouch'un kamerası da Somba'yı gözlemsel olarak takip eder. Somba halkına da ifade şansı verilse, onların da farklı bir bakış açısı olan kendi dünyalarını yansıtacaklarını söyleyebiliriz. Yakın detaylarla ve kültürel danslarıyla gözlemlediğimiz Samba halkına, Damouré'nin yaptığı çarpıc1 yorumla veda ederiz. Damouré “Onlarla dalga geçmek için sebep yok, Somba'yla sadece çıplak oldukları için dalga geçmemeliyiz. Tanrı onların öyle olmasını istedi, onlar da bizim gibi" der. Bu bağlamda, kahramanların batılı önyargılı bakış açısı ve "ötekileştirme" yle özdeşleştikleri ileri sürülebilir. Bu özdeşleştirme kamera arkasındaki batılı beyaz adamın bakış açısının etkisiyle oluşabilir. Etnografik anlatım ve deneyimin yoğun olduğu bu sahnede, etnografik bilginin yanında çok sesli bir anlatım tekniği kullanılarak, izleyicinin edindiği bilgileri süzgeçten geçirmesi ve düşünce kalıplarını zorlaması sağlanmaktadır.

Kahramanlar, Altın Kumsal'a gitmek için ilk yol ayrımına gelirler. Wanzerbeli Mossi'nin nasihatları burada hayata geçmeye başlar. Film sadece üç kahramanımızın değil, özellikle Mossi'nin ve yoldaki diğer kahramanların da etkileşimiyle doğaçlama oluşmaktadır. Bölgenin yaşam biçimi, karakterlerin yardımıyla filmselleşir. Her karakter ve 
bu kişilerle bağlantılı olay ve olgular birbirini tamamlayıcı nitelikte bağlantılıdır. Filmin hikâyesinde hiçbiri tek başına bir anlam ifade etmeyecektir. Karakterler, birer kahramana dönüşmek üzere birbirlerinden ayrılırlar. Lam ve Illo Keta'ya, Damouré Accra'ya gidecektir. İki ay içinde de Accra'da buluşacaklardır.

Accra'ya varan Damouré'de, şapkasıyla kendisinin çok yakışıklı olduğunu doğaçlar ve kahramanımızın üstünde şehir yaşantısının ilk değişimleri gözlemleriz. Şapkasını çıkararak etraftaki insanları selamlar. Modern şehir, Damouré'nin kendini önemli ve özel hissetmesini sağlar. Şehir merkezindeki trafik, teneke satıcıları, şişe yıkayan ve satan Nijer kabileleri bize modern şehrin görselleri olarak ulaşır. Kahramanların kendi aralarında diyaloglardaki doğaçlamalarda "Ne şehir ama beni görebiliyor musun? Kayboldum!" sözleri görüntülerin onları ele geçirdiğinin ve filmsel transa geçtiklerinin göstergesidir. Film çekildikten sonra, stüdyoda ses kaydı kahramanlar tarafından yapıldığı halde, seslendirme anında karakterler olayla bütünleşmekte böylece kendilerini o an orda tekrar o anı yaşar gibi ifade etmektedirler. Filmin bundan sonraki sahnelerinde kahramanların modern şehirde var olma mücadelelerine tanıklık edilir.

Damouré, kereste deposunda işe başlar. Okuma yazma bildiği için kısa süre sonra ustabaşı olur. Kereste sayar. Kolay para kazandığını ifade eden Damouré, güneş gözlüklerini takarak patron gibi etrafındakilere hava atar, meydan okur. Kahraman, modern şehirde kendi "şehirli" kimliğini keşfetmiştir. Okuma yazma bilmesinin onu diğerlerinden daha üstün bir konuma getirmesi içindeki "diğer" kişiliğin ortaya çıkmasını sağlamıştır. Modernizmin yarattığı bu acımasız döngü, Damouré'nin toplum içindeki kimliğinin kısa sürede değişimine etki etmiştir. Modern şehrin kurguladığı kimlik Damouré'yi dönüştüren olgudur.

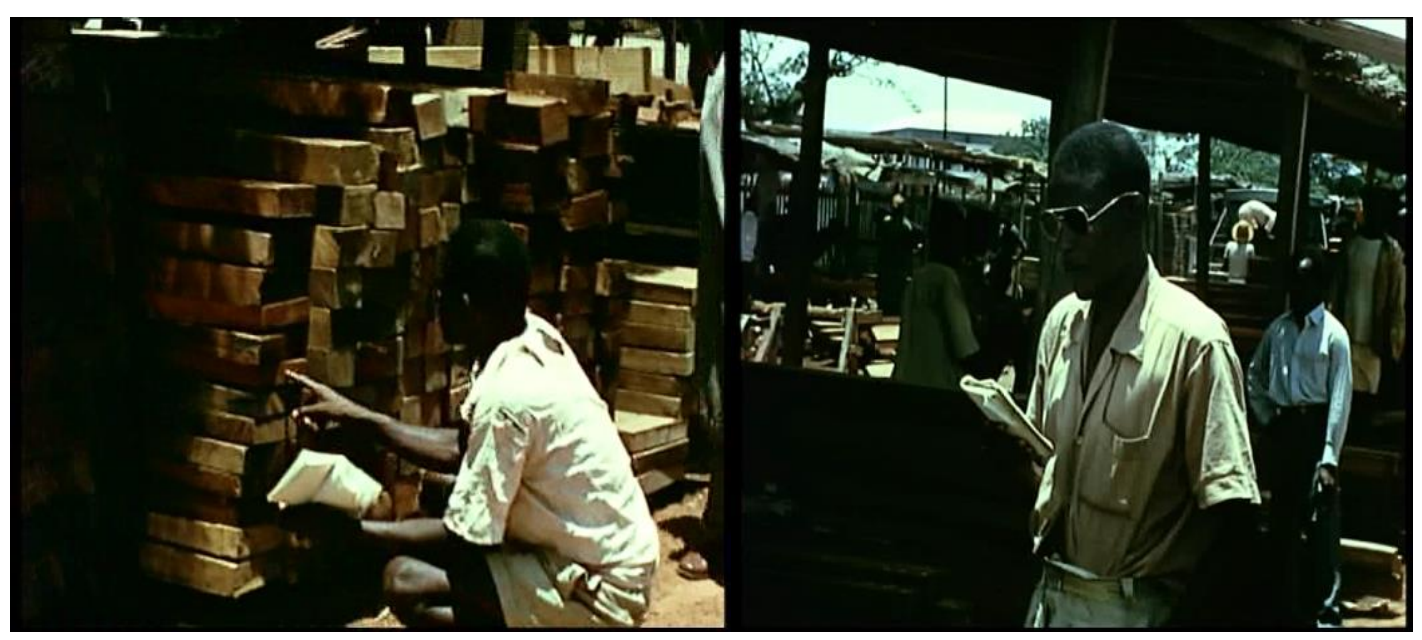

Görsel 1 - "Damouré Zika Kereste Deposu"

Lam, kısa bir süre sı̆̆ır çobanlığı yapar. Kazandığı ilk parayla kıyafetlerini değiştirir. "Boubou" denilen modern kıyafetlerden alır. Orman hayatın terk edeceğini ifade eder. Kıyafeti alır almaz giyer. Diğerlerinden farkh olmak istememektedir. Kıyafet onu diğerlerinden "öteki"leştirmekte, 
giydiği yöresel cübbe ile şehir insanlarn gibi kendini ayn düzeyde hissetmektedir. Ama eski elbiselerini de satmaz ve dönünce onlarn giyeceğini söyler. Eski kıyafetlerini satmaması eski kimliğine döneceğinin görsel bir simgesidir. Çoban kıyafetinden kurtulan Lam'in, artı etraftaki insanlardan bir farkı yoktur. Kumasi Pazarı, Lam için çok büyük ve göz alıcıdır. Pazarda her şeyi görmek için koşar, adeta bir Jaguar gibi hızlı ve çeviktir.

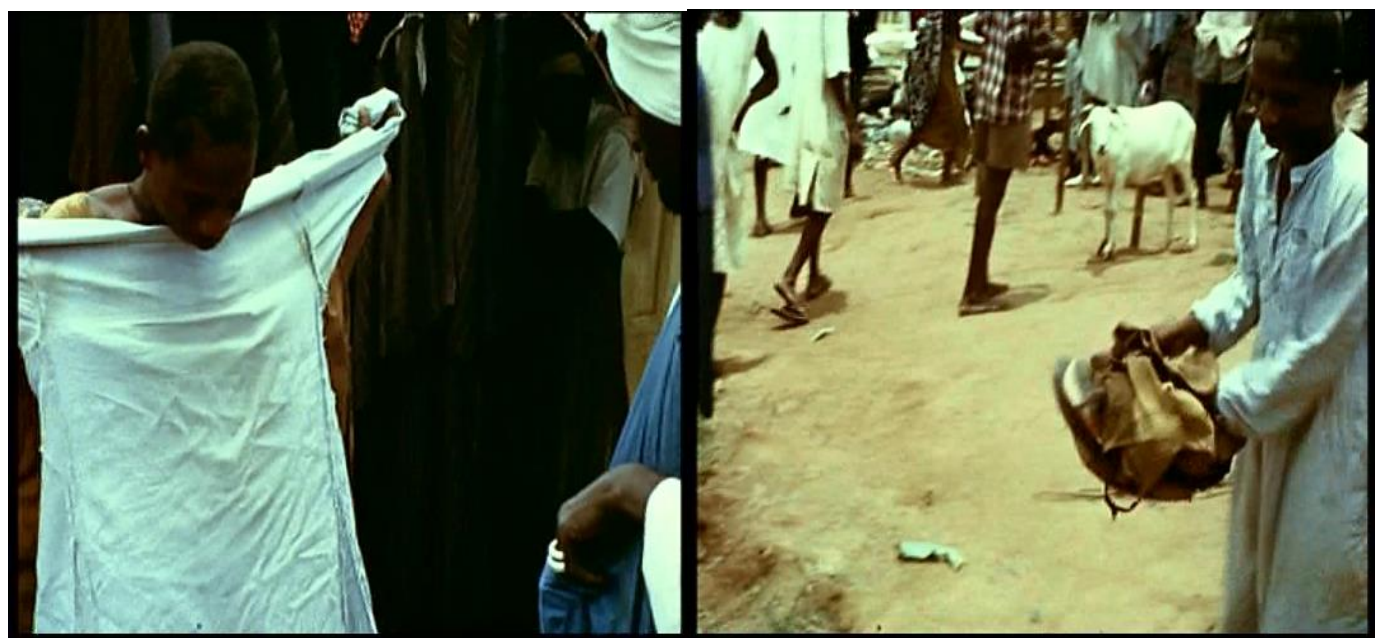

Görsel 2 - "Lam Ibrahima Dia Boubou alırken"

Illo Accra limanında işçi olarak çalışmaktadır. Anlatıcımız Rouch, kısaca Illo'nun işi hakkında bilgi verirken çok az ücretle çalıştığını vurgular. Kahramanlar Illo'nun yaptığı kaya-kaya taşıyıcılığın eleştirirler. Hem yorucu hem de az para kazandıran bir iştir. Hatta kaya-kaya çalışanları çok para harcamamak için az yemek yemektedir. Az parayla çok iş yaptırılmaya çalışan bir sömürgecilik hâkimdir. Kahramanlar sömürgeci düzeni, kendi hikâyeleri üzerinden korkusuzca eleştirirler. Sine-transa geçiş halleri, görüntülerdeki yaşamlarn ikinci kez doğaçlayarak dışa vurulmaktadır.

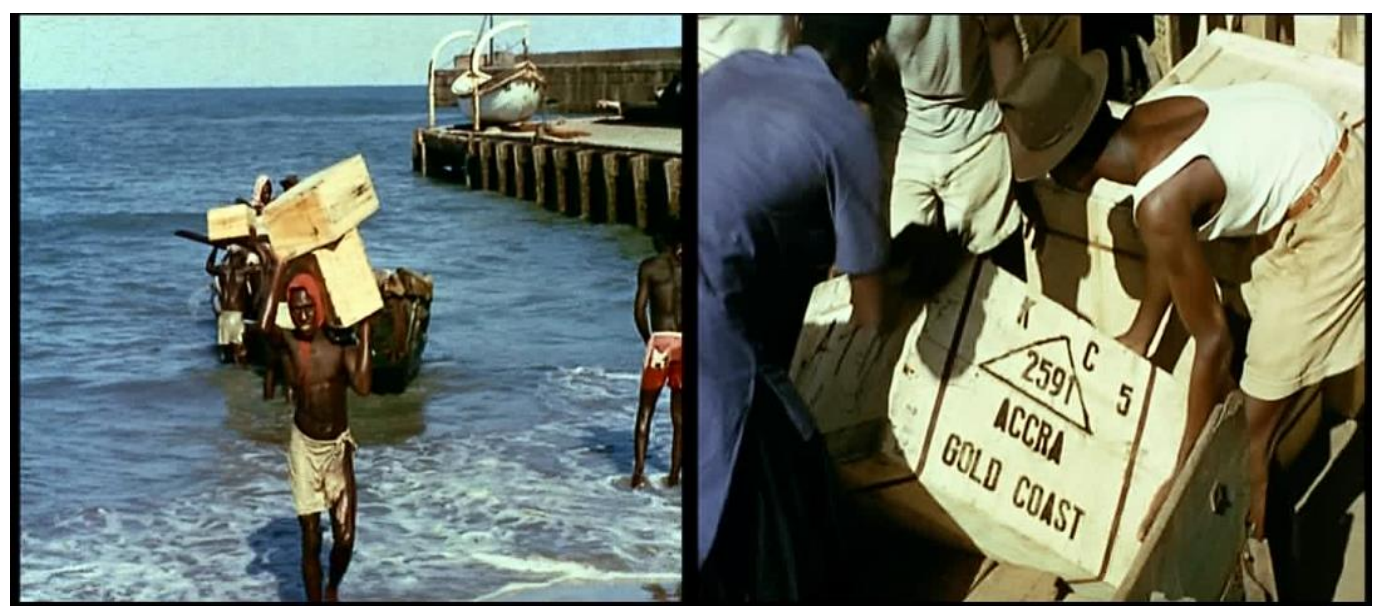

Görsel 3 - "Illo Gaoudel Accra Limanı" 
Kahramanların üçü de, farkh nitelikte becerilere sahiptir. Hepsinde kültürel ve psikolojik değişimler farklı şekillerde belirginleşir. Üçü de farklı sosyal sınıfları temsil eder. Birbirinden farklı, toplumda güçlü ve zayıf temsilleri olan bu karakter yapıları, yönetmen Rouch tarafından inşa edilmiş olabilir. Karakterler arasındaki sınıf ayrımı ile toplumdaki hiyerarşiye gönderme yapılmaktadır. Damouré, toplumdaki sınıflandırmada "Patron" rolünü üstlenmiştir. Damouré, bu sahne sonunda kendisini Jaguar olarak doğaçlar:

Şimdi cadde boyunca yürüyorum, ben Jaguar'1m

- Jaguar ne demek?

- Jaguar, hoş saç tıraşı olan, güçlü, genç adam demek. Sigara içer, etrafta dolaşır, herkes onu izler, İşte Jaguar'ın anlamı bu.

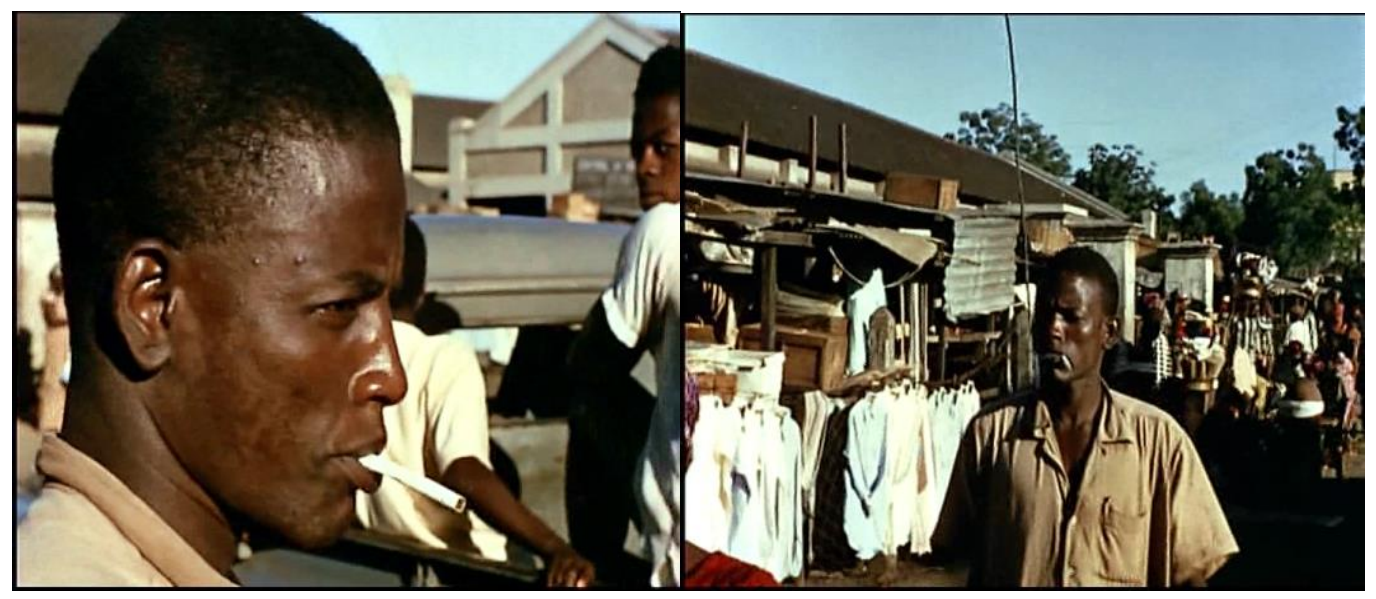

Görsel 4 - "Damouré Zika'nın Jaguarlaşması"

Rouch, Damouré'yi Accra sokaklarında kasıla kasıla dolaşırken görüntüler. Sigara içer, güneş gözlüğü takar, saçına şekil vermiştir. Cesur ve havalı görünür. Jaguar, kibar bir beyefendidir. Etrafındakileri, genç kızları bir Jaguar gibi seyreder. Fonda Jaguar'ı anlatan ritmik müzik, görüntüleri tamamlamaktadır. Damouré sigara, şapka ve gözlüğü ile modern dünyanın yarattığı bir temsil olarak karşımızdadır. Batılı izleyiciye okuma yazma bilen bir Afrikalı gösterilerek kafalarındaki kalıplar zorlanmaktadır. Rouch'un bu kahramanı yaratmasının sebebi, büyük olasılıkla Afrikalıların kültürel kimlikleri üzerine yapışan "ilkel" düşüncesini sarsmaktır. Batılı izleyici eğitimli kibar adama baktıkça "öteki" olarak düşündüğü kişide kendini görmektedir. Rouch, bunu bilerek belirli bir amaca yönelik tasarlamıştır. Bundan sonraki sahnede, Jaguar Damouré'nin ilk kez gördüğü CPP politik toplantısını izlemesine bağlanılmasında Afrika'nın koloni statüsüne gönderme yapılmaktadır. Kahramanların ve Rouch'un politik, sosyal, ekonomik yapiya olan düşünceleri filmin doğaçlama yorumlarında ve görsellerde hayat bulur. Şehirleşmenin getirdiği topluluk bilinci ve politize olma durumu görsel halkın pankartlarıyla yansıtılır. 


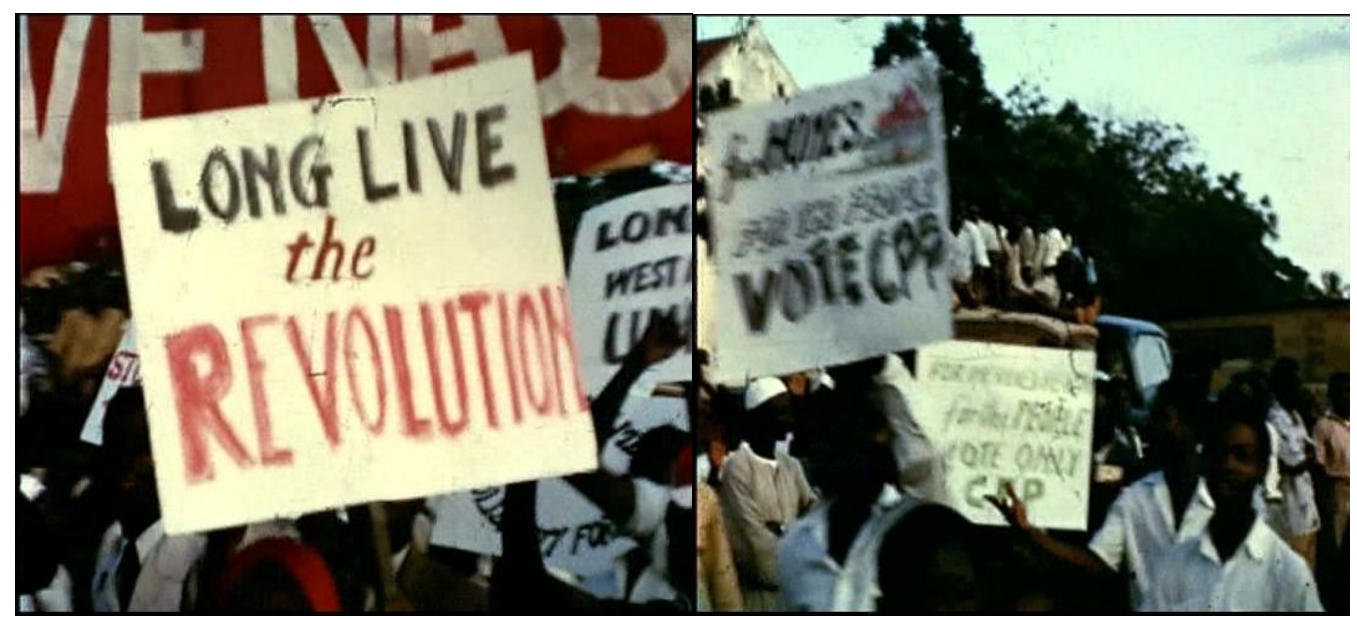

Görsel 5- "CPP kutlamalar1"

Bundan sonraki sahnede sistemle ilgili politize eleştiriler, bir yan karakter olan Duma Besso üzerinden anlatılır. Duma Besso, Nijer'li bir altın madencisidir. Duma ve Lam'ın yolları kesişir. Duma'nın zor şartlar altında madende çalıştığı gözlemlenir. Duma çıplak ayaklarla yollarda yürür. Ayakkabı reklamı ile yaratılan zıtlık, Duma'nın içinde yaşadığı kötü şartları ortaya koymaktadır. Ayrıca, ayakkabı reklamında kullanılan beyaz tenli renkli gözlü kadın figürü sömürgeci yapıyı destekler.

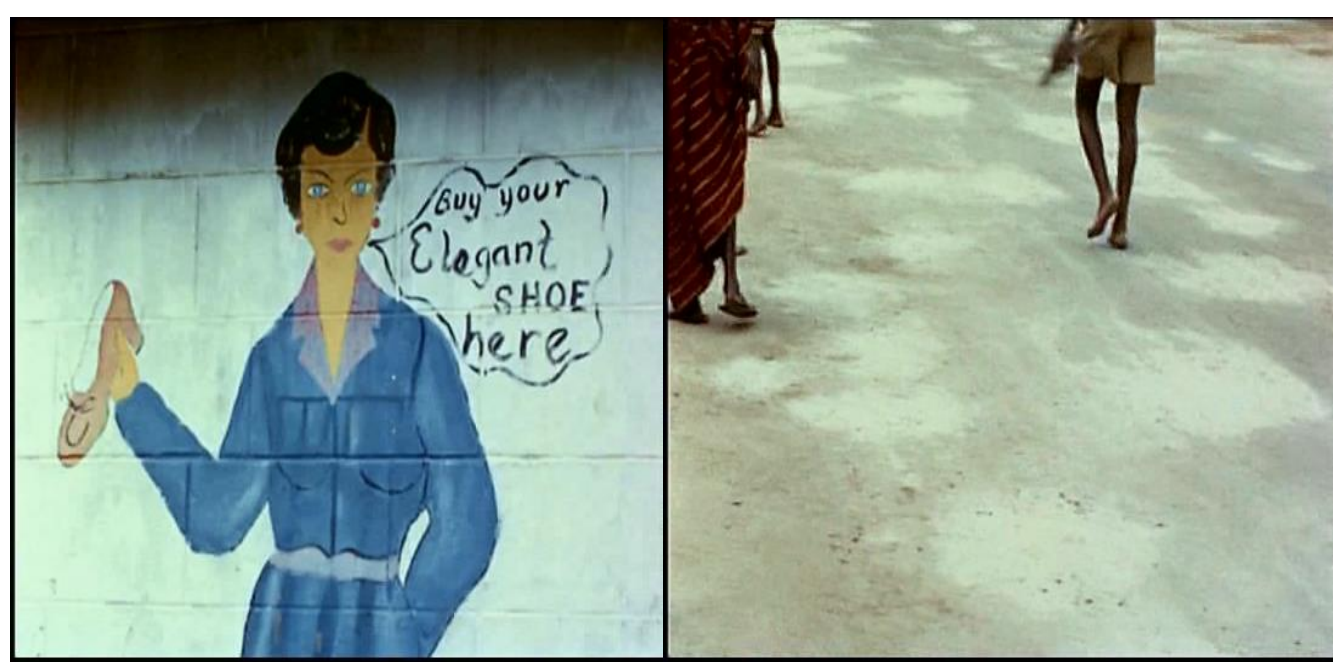

Görsel 6 - "Ayakkabı Reklamı, Duma ve Çıplak Ayaklar"

Film kahramanlar arasında gidip gelmektedir. Illo, limanda bir sığınakta uyurken, Damouré at yarışları izler, barda içki içer, Accra sokaklarında dolanır. Modern kıyafetler içinde kendince krallar gibidir. Sokaklarda dolaşırken çeşitli şehir görüntülerine tanıklık edilir; kilise çıkışında dua eden çocuklar, Martell konyağı reklamı, cenazede dans eden Afrikalılar gibi görüntüler.. Kentin yaşam biçimi hakkında ilginç görüntüler sunulurken modernizm, gelenek, inançlar arasındaki kesişim göze çarpar. Martell konyağı reklamı ve 
kilise Fransız sömürgesini ve etkilerini, cenazede dans eden Afrikalılar geleneği görsel olarak temsil etmektedir.

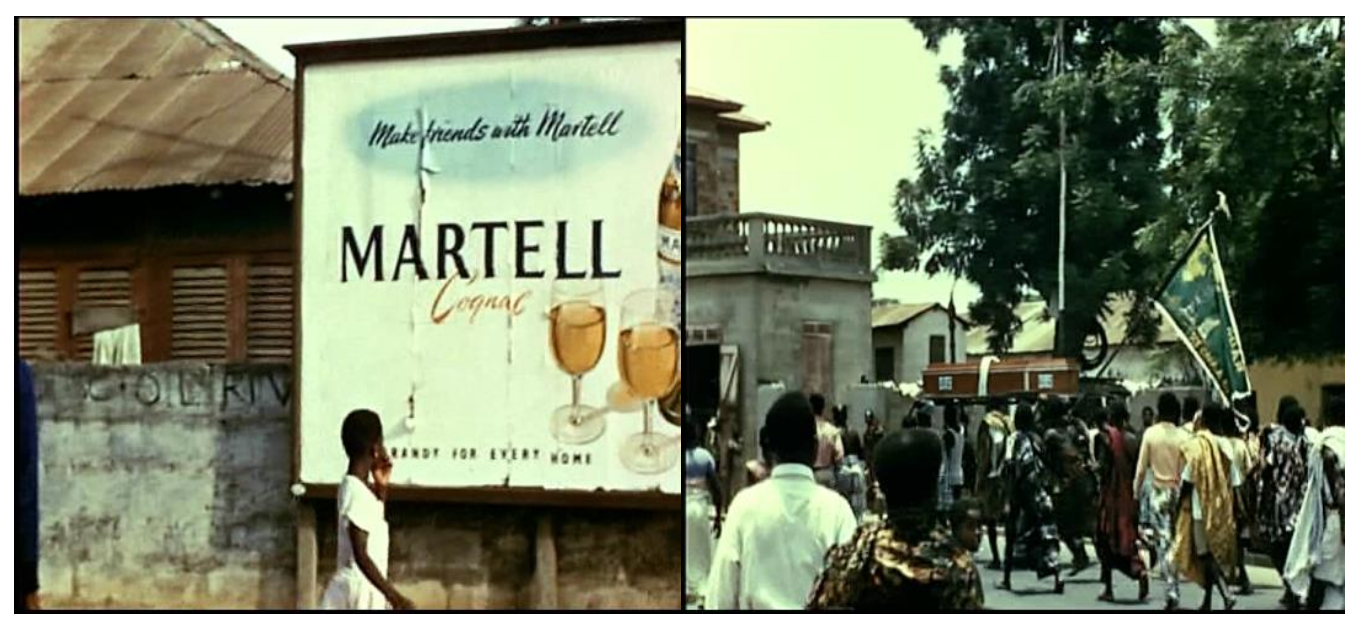

Görsel 7 - "Martell Konyağ̆1 Reklamı ve Cenaze Töreni”

Damouré bundan sonraki sahnede, seçim kampanyasında fotoğrafçıdır. Okuryazar kibar Jaguar'ın temsilinde "elinden her iş gelen" bir kahraman konumundadır. Özgürlük isteyen halkın sesi bu karelerde iyice yükselir ve Afrikalı sömürgecilik karşıtı liderin görüntüleri ile desteklenir. Lider Kwame Nkrumah, ulusal kiyafetleri ve kameraya olan bakışları ile sanki filme destek vermektedir. Film, sömürgecilik anlayışına olan tavrını devrimci liderle açık açık sunmaktadır. Damouré de fotoğrafçı olarak kampanyada yerini almıştır. Damouré'nin fotoğraf makinasını kullanabildiğiyle ile ilgili bize daha önce bilgi verilmediği için, Jaguar'ın her işten anlayan, her işi bilen kişilik modeli Batılı kimliğin yansıması olarak düşünülebilir. Damouré'nin temsili ve gerçeği arasındaki çizgi her sahnede farklılık gösterir. Kimi zaman Jaguar, kimi zaman ezilen bir Afrikalı olan Damouré'nin seçim kampanyasındaki coşkusu özgürlük savaşı içindir. Sömürge altındaki insanların coşkulu tavırları ise ilginçtir.

Filmin devaminda kahramanlar bir araya gelmeye başlarlar. Damouré ve Illo trene binip Lam'ın yanına Kumasi'ye giderler. Damouré patron tavırlarını sürdürmektedir. Çantasını Illo'ya taşıtır. Illo'yu okuma yazma bilmediğini söyleyerek aşağılar. Damouré batının onlara bakışını doğaçlamaktadır. Baskın karakter Damouré Lam'ın satış yerindeki hiçbir şeyi beğenmez. Her şeyin en iyisini ben bilirim tavırlarıyla dükkânı düzenler. Damouré, dükkân mallarını arttırır. Yazıcılık yapar. Diğer yandan fotoğraf makinesi, saat, ilaç, şapka, mendil, dinsel fotoğraflar (Âdem ve Havva), michelin yol haritası gibi birçok şeyi pazarlar. Bütün yeteneklerini ticarete için kullanmaktadır. Karakterlerin toplumsal dönüşümleri küresel dünyanın eşyaları üzerinden oluşmaktadır. Damouré genç bir adama sattığı siyah bir şapka ile "işte sen de bir jaguarsın" demektedir. Artık herkes jaguardır, patrondur, kraldır, kraliçedir. Gitme vakti geldiğinde doğaçladıkları ilk cümle şöyledir: "Bu kent insan bozuyor adamım, gitmemiz gerek". Dükkânlarna veda ederler; Lam, Damouré, Duma ve Illo Şirketine. Dört kahramanın Jaguarlaştığı en önemli mekândır burası... 
Kahramanlar, Ayoru'ya getirmek için bütün eşyalar toplarlar. Kamyonetlerine binerler ve kamyonetin üzerinde Accra'ya; modern dünyaya veda ederler. Modern dünyanın gündelik yaşam üzerindeki etkisinin her geçen gün artacağının, değişim ve dönüşümlerin kaçınılmazlığının haritası ortaya çımaktadır. Birçok kişi mevsimlik işçi olarak para kazanmak için buraya gelse de, yağmurlardan önce buradan ayrılırken kazandıklar para ile birlikte aşınmış kültürel kimlikleriyle köylerine dönmektedir.

Rouch bize dört kahraman üzerinden aslında mevsimlik işçi olarak Gana'ya göç eden bütün insanların hikâyesini anlatmıştır. Her karakter sömürge altındaki toplumda farkl yetenekteki kişileri temsil eder. Mevsimlik maceranm kültürel kimlik, sömürgecilik, öteki gibi kavramlara ayna tuttuğu gözlemlenir. Bu kavramlar, izleyiciyi kalıplaşmış düşünceleri yeniden düşünmeye çă̆ırır.

Dönüşleri Rouch'un sesinden anlatılır. Dönüş yolu için atalarnna ait olan Alfa Hano, Babatu yolunu takip ederler. Rouch, onların "Modern Dünyanın Kahramanları" olduğunu ifade eder. Kahramanlar mahkûm ya da köle olarak değil, bagajlarıla insan gibi dönmektedirler. Film çekildiği tarihte halk özgürlüklerini tam olarak ilan etmese de kurdukları parti, liderleri ve coşkuları bağımsızlıkların ilan etmeye az kaldığının habercisidir. Kahramanlar artık tam bir jaguardır. Onları jaguar yapan getirdikleri, eşyalar, hediyeler, hikâyeler, deneyimler ve modern dünyanın yalanlarndır. Bütün zorlukları yaşamış ve göğ̈̈s germeyi öğrenmişlerdir. Ayoru'da büyük bir coşkuyla karşılanırlar. Kıyafetleri ve getirdikleri eşyalarla kendi dünyalarının "öteki"si olmuşlardır. Fakir insanlara gösterdikleri hasır halı üzerindeki güçlü aslan figürü ile kendilerini özdeşleştirirler. Onlar artık güçlü ve mücadelecidir.

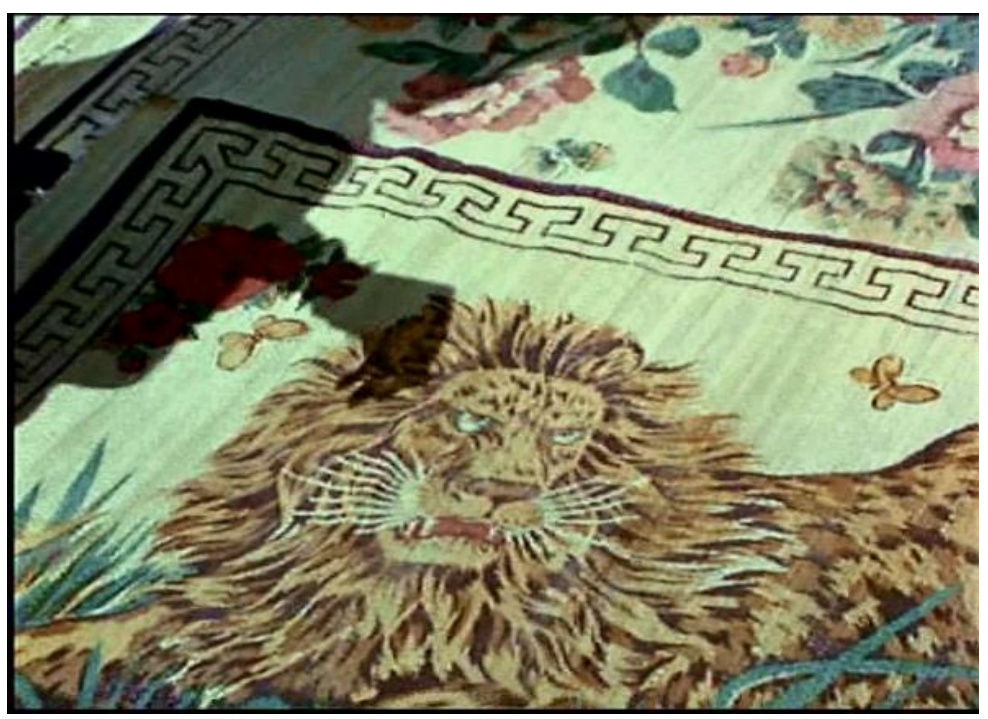

Görsel 8 - "Aslan Figürlü Hasır Halı”

Eşyaları Ayoru'da dağıtarak, getirdikleri her şeyi vererek kendi özlerine dönmeye çalışırlar. Modern dünyanın etkisi getirilen eşyalar üzerinden etkisini göstermektedir. Kahramanlar modern şehrin kendilerine verdiği mücadeleci ve cesaretli tavırla kendi dünyalarnnda da jaguardır artık. Illo gelir gelmez hoşlandiğı kıza evlenme teklif eder. Duma daha güçlü olarak tarlasında çalışmaya devam eder. Bir baston ve şemsiye ile Lam sürüsünün başına döner. Başka bir şeye ihtiyacı olmadığııı söylemektedir. 


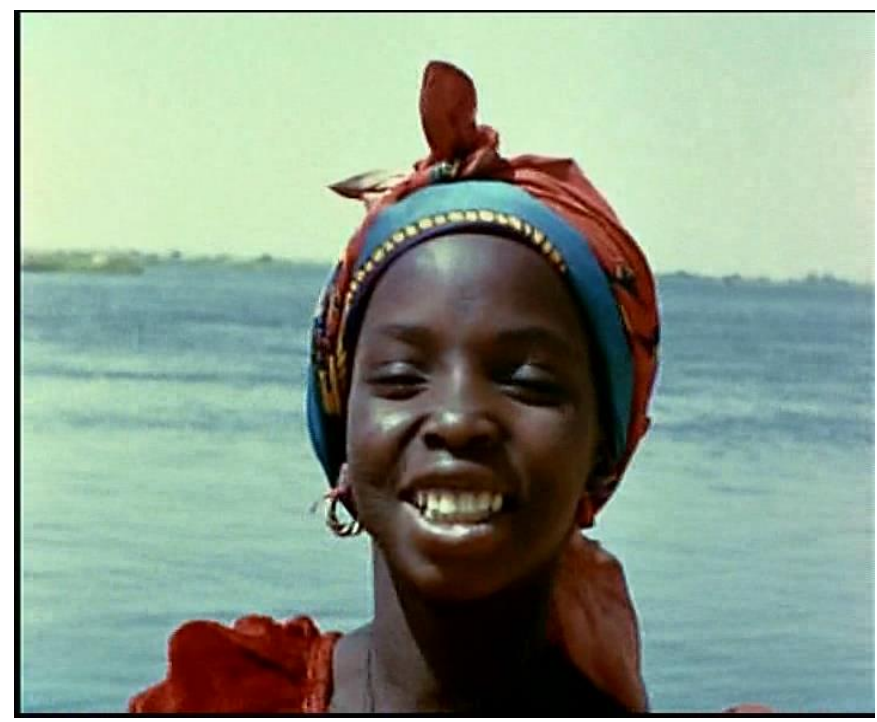

\section{Görsel 9 - "Nijeryalı Genç K1z"}

Damouré ise her zamanki gibi kendine olan güveniyle nijer kızlarının gönlünü fethetmeye devam eder. Güzel ve gülen bir nijerli genç kız karesinin üzerine doğaçlanan "Çok Yaşa Nijerya" sözleriyle film biter. Gülümseyen nijer kızı finaliyle, mutlu bir gelecek vadeden ülkeye simgesel olarak gönderme yapılmaktadır. Karakterler film sonunda, köylerine döndüklerinde eski kimliklerine kavuşuyor gibi görünse bile, film sürecinde yaşadıkları kültürel değişim ve dönüşüm sonucunda bundan sonra hayatlarında aynı kimlikle var olamayacakları açıktır. Diğer taraftan, Rouch da onları bu sürece dâhil ederek değişimlerine aracılık etmiştir.

Filmi, etnografik araştırma yöntemlerinin kullanımı açısından değerlendirdiğimizde, Rouch'un burada uzun yillar geçirip Jaguar'dan önce bu bölgede birçok film gerçekleştirdiği gerçeğine dayanarak, yeterli alan araştırmasına sahip olduğunu söyleyebiliriz. Rouch, katılıml gözlem metodunu kullanarak ve zaman içinde paylaşımcı antropoloji fikrini hayata geçirerek, filmlerinde farkl pratikler uygulamıştır. Bu süreçte, aktif gözlemin kültürleri etkileme olasılığı yüksektir. Öznelerin filmin yaratımı aşamalarında aktif rol alması, gözleyen ve gözlenen arasındaki ilişkiyi altüst eder. Bu süreçte, roller değişse bile yönetmenin olgularn etkileme gücü yüksektir. Jean Rouch'un antropolog kimliği onun sinemasal süreci yönünden çok önemlidir. Çünkü Rouch, kimi zaman antropolog kimi zaman yönetmen olarak iki önemli kimliği birleştirmiş, kavram ve metotları uygulayıp kuramsallaştırmıştır.

Filmi sinema dili yönünden incelediğimizde dış ses kullanımı etnografik bir anlatıcı gibi değil, kahramanlarm yorumlarm destekler niteliktedir. Rouch seslendirmeyi etnografik anlatımlar yapmak için kullanmaz. Yardımo bir hikâye anlatıcı olarak karşımıza çıkar. Hikâyenin asıl anlatıcıları kahramanlardır. Rouch'un bu anlamda filmi yönlendirici etkisi zayıftır. Gerek doğal sesler gerekse, etnik müziklerle film kurgulanmıştır. Müzikler filme hareket ve mizah vermektedir. Filmdeki kamera kullanımı eyleme doğrudan katılan biri gibidir. Katılımo kamera, dışarıdan olaylarn gözlemleyen bir tarzda hareket etmez. Yerel öznelere yakın, samimi sıcak bir kamera kullanımı hâkimdir. Zaman zaman öznel kamera kullanımlarn dikkat çeker. Flaherty'in katılımcı kamerası ile Vertov'ıun doğaçlama hayatı yakalama sentezi burada harekete geçmektedir. Genel ve yakın planlarla devamlılık sorunu ortadan kalkar. Kameranın varlı̆̆ına dair fark etme durumu oluşmaz. Yönetmen sadece filmi 
kamera kullanımı üzerinden deneylemez, aynı zamanda gerçek hayatı anlatım tarzı ile de farklı yaklaşımlar denemiştir. Rouch, kurgu yapmaya karşı olsa da Jaguar içinde kurgusal öğeleri barındıran bir filmdir. Hem teknik hem de içerik olarak gerçeğin üzerinden kurgulanmış bir dünya sunulur. Tümüyle gerçeklik iddiası bulunmayan, gerçekliği tasvir eden kurgu yöntemi kullanılarak, gerçekliğin bir yorumu olarak karşımıza çıkar. Bu yöntemle Rouch belgesel sinemada gerçeklik konusuna da farkl bir yaklaşım getirir. Rouch "Jaguar benim ilk uzun metrajlı filmim, ilk kurgu filmim ve beni daima etkiledi. Şimdi yapacağım tüm filmler Jaguar demiştir (Rouch ve Feld, 2004: 164). Rouch kendi sinema anlayışııı bu filmde bulmuş ve yapılandırmıştır.

\section{Sonuç}

Belgesel sinemanın öncülerinden olan Robert Flaherty'in yaklaşımlarn etnografik belgesel film yapım süreci için çok önemli veriler içermektedir. Etnografik belge amaçlı ya da etnografik veri toplamak için çekilen filmleri, etnografik belgesel film olarak değerlendirmek yanlıştır. Etnografik belgesel film sadece kültürel bir belge değil, içinde sinematografik biçim ve yöntemleri barnndıran, estetik ve etik değerlere sahip, belirli bir söylemi olan sinema yapıtlarn olmalıdır. Geçmişte ve günümüzde bilinçli ya da bilinçsiz olarak sömürgeci anlayış doğrultusunda biçim ve içeriklere sahip olan etnografik belgesel filmlerin etik sorunları hala devam etmektedir.

Kültürel antropolojinin kavramsal özellikleri ve etnografik araştırma yöntemleri, belgesel sinemanın etnografik bakış açısı ile oluşumunda önemli rol oynar. Etnografik araştırma yöntemleri, belgeselin özellikle araştırma ve yapılanması sürecinde belgesel sinemacı için yol göstericidir. Etnografik araştırma yöntemlerinin belgesel sinema içinde doğru kullanımı, filmin söyleminde de etkili olacaktır. Etnografik belgesel sinemanın öncüsü Rouch, 1957 yılına kadar deneme çekimleri gerçekleştirerek, bundan sonra çektiği filmlerle belgesel sinema yapımında dikkat edilmesi gereken verileri ortaya koymuştur.

Jean Rouch, antropolog bakış açısını belgesel sinemanın geçirdiği süreç çerçevesinde yorumlayarak etnografik belgeselde olması gereken pratikleri kuramsallaştırmayı başarmıştır. Belgesel sinemada etnografik bakış açısının doğru ilerlemesi ve filmin kendi gerçekliğini ortaya çıkarması yönünden bu yaklaşım çok önemlidir. Etnografik belgesel filmler çok yönlüdür ve bütün yönleriyle kendini ortaya çıkarması, alan araştırması ve paylaşımo antropoloji yöntemleriyle mümkün olur. Film yapımasının kendini diğer dünyalara açması, etnografik araştırmanın sosyal ağı içinde meydana gelir. Rouch'un Songhay kültürüyle bağlantısı onun filmlerinde zincirleme bir anlatı oluşturur. Fakat filmlerindeki zincirleme bă̆ sadece yerel kültürlerin özellikleri yönünden değil, sinematografik olarak da birbirini tamamlamaktadır. Etnografik araştırma yöntemleri sayesinde Rouch, bu süreçte kültürle ilgili bilgilerini yaşayarak inşa etmiştir. Ayrıca kamera kullanımı, fikrin ve filmin doğaçlaması, dış ses ve müzik kullanımı gibi birçok unsuru kullanarak, klasik etnografik belgesel film anlayışından uzaklaşmış kendi sinema dilini yaratmıştır. Batının yerel kültürlere olan bakış açısını, ortaya koyduğu sinema dili ile eleş̧tirmiş̧tir. Rouch, sinemada farklı yöntemleri deneylemeyi sevdiği gibi, sabit bakış açılarına karşı da sinemasıyla başkaldırmıştır. Yerel kültürlere sunduğu imkânlarla, izleyici ile kültürler arasında aracısız bağ kurma çabası göstermiştir. Rouch'un bu süreci tam anlamılla objektif olarak sunduğu iddia edilemese de, ciddi bir adım olarak kabul edilmelidir.

Jaguar filmini ele aldığımızda, Rouch kültürel değişimleri bir parça yakalamış olmasına rağmen, tam olarak sosyo-kültürel sonuçlarn veremediği gözlemlenir. Stnırl bir anlatım söz konusudur. Film, kahramanlarının kendi "öteki"liklerini keşfetme durumuna ve "öteki" üzerinden 
yapılabilecek yorumlara açıktır. Fakat genel olarak diğer göçmenlerin ne yaptıklarn ile ilgili bilgiler izleyiciye verilmez. "Öteki"ne bakış açısı konusunda sadece batılı dünyanın yerel kültürlere karşı önyargılı olmadığı, bunun yanında kültürlerin de kendi aralarında önyargılı bir bakış açısına sahip olabileceği gözlemlenir. Rouch'un gözlemlediği ve kurguladı̆̆ı bazı kimlikler, batının oluşturduğu kimlik kodlarından ibarettir. Kahramanlarımı Accra'da modern dünya tarafindan kurgulanmış kimlikleriyle hareket ederler. Rouch'un filme olan yaklaşımındaki farkındalık ve öğrendiklerini sentezlemesi bugünün etnografik belgesel sineması için yol göstericidir. "Etnokurmaca" nın yarattı̆̆ dünya bizi orada yaşayan insanlarn yaşamlarna dair düşünmeye sevk eder. Bu noktada "etnokurmaca"nın klasik belgesel anlayışına farkh bir bakış açısı getirdiği söylenebilir. Rouch'un Jaguar filmi düşünebilen, karar verebilen, yorumlayabilen bir "öteki" ortaya çıkarır. Bu izleyicinin kafasındaki "öteki" imgesine gönderme yapar. Rouch'un kameranın arkasinda bir aktör konumunda olması Jaguar'ın göç, kimlik, sömürgelik gibi kavramlara dair söylemlerini zedelememektedir. Yönetmenin müdahale ve bakış açısının hiç olmadığını söylemek sinemanın olanakları çerçevesinde imkânsız gözükmektedir.

Rouch'un sinema serüveninde özeleştiri yaparak kendini yapılandırması da çok önemlidir. Rouch'un kendi işlerini eleştirmesi ve ona karşı yapılan eleştirileri dikkate alması, onun etnografik belgesel film adına gösterdiği çabanın göstergesidir.

Rouch sinemada gerçeklik teorisine de farklı yaklaşımlarda bulunmuştur. Birebir mutlak gerçekliğin oluşması mümkün olamayacağından Rouch, gerçeği kahramanlar üzerinden yorum olarak izleyiciye sunar. Gerçekle kurmaca arasında gidip gelen film, gerçeğin birebir temsili iddiasında değildir. Rouch'un iddiası kavramların içindeki mesajlarda saklıdır.

Rouch, etnografik belgesel filmlerinde kültür, öteki, kimlik, çokseslilik gibi kavramlarn uzun yillar önce hayata geçirmiş bir yönetmen olarak sinema tarihinde özel bir yerde olmalıdır. Hala tartışlmakta olan bu kültürel kavramlar, Rouch'un sinemasında önemli yer tutmaktadır. Rouch sinemasındaki etnografik ilişki yönetmen kadar karakterlerin de sesinin duyulmasını sağlamaktır. İkinci Dünya Savaşı sonrası Afrika'nın değişim ve dönüşümlerine tanıklık eden Jaguar, anlatımın gerçek kahramanlar üzerinden başarmıştır. Rouch'un o günün şartlarında sömürgecilik, kültürel değişim gibi konulara cesaretli yaklaşımları önemsenmelidir. Başkaları tarafindan yapılandırnlmış, dış sesle yönlendirilmiş olan etnografik sinema işlevini yerine getiremeyecektir. Jaguar, yerel öznelerin kendilerini temsil etme yetilerini ve başarıların ortaya koyarak diğer filmlerin önünü açacak nitelikte öncü bir belgesel olmuştur. Rouch, kuramsallaştırdığı sinemasıyla gelenekçi bakış açısını da sorgulamıştır.

Bütün bu bilgiler doğrultusunda;

1. Etnografik belgesel film yapımında uzun süreli gözlem ve katılım önemlidir.

2. Gözlem ve katılım uzun bir süreçte belgeselin gerçekliğine dair yapılan yorumun ortaya çıkmasını să̆lar.

3. Paylaşımcı antropoloji belgesel film yönetmenine geri dönüşüm sağlayarak, yönetmende farkındalık yaratır.

4. Katılımo kamera kullanımı filmin doğaçlamasına katkıda bulunarak, samimi görüntülerin filme yansımasımı sağlar. 
5. Doğaçlama ve Sine-trans deneyimleri, etnografik belgesel filmde "gerçeklik" olgusuna yorum getirerek filmsel gerçekliği oluşturur.

6. Etnografik belgesel filmlerde yerel gerçeklerin ve etnik portrelerin gösterilmesi belgesel sinemanın işlevleri açısından önemlidir.

7. Jaguar sömürgecilik, öteki, kültürel kimlik gibi kavramlara ayna tutarak siyasal bir portre çizer. Bu anlamda etnografik belgesel film yerel kültürlerin temsili özelliğini taşıyabilir.

Sonuç olarak, Rouch'un deneyimleri etnografik sinemanın önünü açan, bugün bile uygulanması gereken birçok yöntem içermektedir. Rouch'un Jaguar filmi, belgesel film tarihinde ciddi bir çaba olarak yerini almalıdır. Etnografinin ve hayal gücünün sinırlarl, Rouch'un sinemasında olduğu gibi günümüz etnografik belgesel filmlerde de zorlanmalıdır

\section{Kaynakça}

Adalı B. (1986), Belgesel Sinema, İstanbul: Hil Yayınları.

Altıntaş M. (2002), Jean Rouch Ve Sinema Gerçek Üzerine Birkaç Not, Belgesel Sinema Dergisi, İstanbul: Sayı 1

Cereci S. (1997), Belgesel Sinema, İstanbul: Şule Yayınları.

Emerson, M. Robert, Vd. (2008). Bütün Yönleriyle Alan Çalışması, Çev. A. Erkan Koca, Ankara: Birleşik Yayınları.

Koçer S. (2008), Jean Rouch Ve Etnokurmaca: Gerçekle Kurmaca Arasında, Altyazı Dergisi, Mart Sayıs1.

Makal O.(2002), Fransız Gerçekçi Okulundan Jean Rouch, Belgesel Sinema Dergisi, İstanbul: Sayı 1

Nannicelli T. (2006), From Representation To Evocation: Tracing A Progression In Jean Rouch's Les Magiciens De Wanzerbé, Les Maîtres Fous, And Jaguar, Visual Anthropology.

Pempecioğlu N. (2005), Belgesel Sinema Üzerine Yazllar-Biçim Olarak Belgesel, Ankara: Babil Yayınları.

Rouch J., Feld S. (2004), Ciné-Ethnography,, Minneapolis: University Of Minnesata Press.

Stoller P. (1992), The Cinematic Griot: The Ethnography Of Jean Rouch, Chicago:University Of Chicago Press.

Scheinman, D. (1998), The 'Dialogic Imagination' Of Jean Rouch: Covert Conversations In Les Maitres Fous, In Documenting The Documentary: Close Readings Of Documentary Film And Video. Eds: Barry Keith Grant And Jeannette Sloniowski, Detroit: Wayne State University Press.

Susar A. F. (2005). Etnolojik Belgeleme-Etnografik Film Ve Sözlü Tarih Çalışmalarımın Antropolojideki Yeri", Gelenekten Geleceğe Antropoloji, Derleyen: Belkıs Kümbetoğlu, Hande Birkalan Gedik, İstanbul: Epsilon Yayınları

Ulutak N. (1998), Belgesel Sinemanın Öncüsü: Robert Flaherty, Anadolu Üniversitesi İletişim Bilimleri Fakültesi Dergisi Kurgu, Sayı: 5 
Ulutak N. (2003), Robert J. Flaherty Ve Kuzeyli Nanook, Eskişehir: Anadolu Üniversitesi Yayınları.

Yüksel C. (2006), Belgesel Sinemanın Doğruya Ulaşma Yolları, Selçuk Üniversitesi İletişim Fakültesi Dergisi Cilt.4 